\title{
Improved identification of primary biological aerosol particles using single-particle mass spectrometry
}

\author{
Maria A. Zawadowicz ${ }^{1}$, Karl D. Froyd ${ }^{2,3}$, Daniel M. Murphy ${ }^{2}$, and Daniel J. Cziczo ${ }^{1,4}$ \\ ${ }^{1}$ Department of Earth, Atmospheric and Planetary Sciences, Massachusetts Institute of Technology, \\ Cambridge, Massachusetts, UK \\ ${ }^{2}$ NOAA Chemical Sciences Division, Boulder, Colorado, USA \\ ${ }^{3}$ Cooperative Institute for Research in Environmental Sciences, University of Colorado, Boulder, Colorado, USA \\ ${ }^{4}$ Department of Civil and Environmental Engineering, Massachusetts Institute of Technology, Cambridge, MA, USA \\ Correspondence to: Daniel J. Cziczo (djcziczo@ mit.edu)
}

Received: 12 December 2016 - Discussion started: 15 December 2016

Revised: 18 April 2017 - Accepted: 6 May 2017 - Published: 16 June 2017

\begin{abstract}
Measurements of primary biological aerosol particles (PBAP), especially at altitudes relevant to cloud formation, are scarce. Single-particle mass spectrometry (SPMS) has been used to probe aerosol chemical composition from ground and aircraft for over 20 years. Here we develop a method for identifying bioaerosols (PBAP and particles containing fragments of PBAP as part of an internal mixture) using SPMS. We show that identification of bioaerosol using SPMS is complicated because phosphorus-bearing mineral dust and phosphorus-rich combustion by-products such as fly ash produce mass spectra with peaks similar to those typically used as markers for bioaerosol. We have developed a methodology to differentiate and identify bioaerosol using machine learning statistical techniques applied to mass spectra of known particle types. This improved method provides far fewer false positives compared to approaches reported in the literature. The new method was then applied to two sets of ambient data collected at Storm Peak Laboratory and a forested site in Central Valley, California to show that 0.04$2 \%$ of particles in the $200-3000 \mathrm{~nm}$ aerodynamic diameter range were identified as bioaerosol. In addition, $36-56 \%$ of particles identified as biological also contained spectral features consistent with mineral dust, suggesting internal dustbiological mixtures.
\end{abstract}

\section{Introduction}

Biological atmospheric aerosol (or bioaerosol) has recently garnered interest because certain species of bacteria and plant material might impact climate via the nucleation of ice in clouds (Hiranuma et al., 2015; Möhler et al., 2008). However, many field-based measurements of ice nuclei and ice residuals do not indicate that bioaerosol is a major class of ice-active particles (Cziczo et al., 2013; DeMott et al., 2003; Ebert et al., 2011). While modeling efforts suggest that biological material is not significant in ice cloud formation on a global scale, uncertainties continue to exist because field measurements of ice-nucleating particles are currently sparse (Hoose et al., 2010; Sesartic et al., 2012).

In this paper, "bioaerosol" is defined as primary biological aerosol particles (PBAP) (i.e., airborne whole and fragmentary bacteria, pollen and spores) and particles that contain fragments of PBAP as a part of an internal mixture. Measurement techniques specific to bioaerosol include the collection of aerosol on filters followed by analysis with microscopy techniques, either electron microscopy (EM) or optical microscopy coupled with fluorescent staining of the samples (Amato et al., 2005; Bauer et al., 2002, 2008; Bowers et al., 2009, 2011; Griffin et al., 2001; Matthias-Maser and Jaenicke, 1994; Pósfai et al., 2003; Sattler et al., 2001; Wiedinmyer et al., 2009; Xia et al., 2013). Aerosol samples collected in the atmosphere have been cultured for the identification of the microbial strains present (Amato et al., 2005, 2007; Fahlgren et al., 2010; Fang et al., 2007; Griffin et al., 2001, 2006; Prospero et al., 2005). 
In situ techniques specific to biological samples are typically based on the fluorescence of biological material following UV excitation. Examples include the wide-band integrated bioaerosol sensor (WIBS) which is available commercially (Kaye et al., 2000, 2005). WIBS has been successfully deployed in several locations (Gabey et al., 2010; O'Connor et al., 2014; Toprak and Schnaiter, 2013). Using fluorescence to detect biological aerosol can have interferences, however. For example, polycyclic aromatic compounds or humic acids can have similar fluorescent properties (Gabey et al., 2010; Pan et al., 1999). Cigarette smoke has similar fluorescent properties to bacteria (Hill et al., 1999). In an attempt to address interferences, WIBS collects fluorescence information using several channels with different wavelengths while also measuring the size and shape of the particles. Table 1 summarizes some recent measurements of bioaerosol. More information can be found in recent reviews focused on bioaerosols in the atmosphere, such as Després et al. (2012).

Measurements of bioaerosol in the free and upper troposphere, where they could be relevant to cloud formation, remain scarce. Four of the recent studies reported in Table 1 used an aircraft to access altitudes higher than $4000 \mathrm{~m}$ (DeLeon-Rodriguez et al., 2013; Pósfai et al., 2003; Twohy et al., 2016; Ziemba et al., 2016). Two of these used the WIBS to report vertical profiles of fluorescent particles (Twohy et al., 2016; Ziemba et al., 2016). In the remaining two cases, aerosols were collected on filters and analyzed off-line. There can exist significant uncertainty in these measurements. A recent aircraft-based study by DeLeon-Rodriguez et al. (2013) reports analysis of high-altitude $(8-15 \mathrm{~km})$ samples taken before, after and during two major tropical hurricanes. The abundances of microbes, mostly bacteria, were reported to be between $3.6 \times 10^{4}$ and $3.0 \times 10^{5}$ particles $^{-3}$ in the $0.25-1 \mu \mathrm{m}$ size range. The methods and conclusions of this study were re-evaluated by Smith and Griffin (2013), who argued that in some instances the reported concentrations of bioaerosol were not possible because they exceeded the total aerosol by several factors. The samples were also taken over periods of hours, possibly including sampling in clouds when the high-speed impaction of droplets and ice can dislodge particles from the inlet (Cziczo and Froyd, 2014; Froyd et al., 2010; Murphy et al., 2004).

Although difficult, measurements of bioaerosol in the upper troposphere are necessary in order to constrain their influence on atmospheric properties and cloud formation processes. All of the techniques discussed above, except for WIBS, are off-line and require expertise in sample processing and decontamination. WIBS is a possible in situ detection technique for bioaerosols, but it is relatively new and, as a result, has a short deployment history. There has been considerable interest in using aerosol mass spectrometry techniques to measure bioaerosol. Single-particle mass spectrometry (SPMS) has been successfully used since the mid-1990s to characterize the chemical composition of atmospheric aerosol particles in situ and in real time (Murphy,
2007). The ability of SPMS to simultaneously characterize volatile and refractory aerosol components makes it an attractive tool for investigating the mechanisms of cloud formation (Cziczo et al., 2013; Friedman et al., 2013). The general principle behind SPMS, and in particular the instrument discussed in this paper, the Particle Analysis by Laser Mass Spectrometry (PALMS), is the use of a pulsed UV laser for the ablation and ionization of single aerosol particles. Ions are then accelerated into a time-of-flight mass spectrometer. Laser ablation or ionization used with SPMS produces ion fragments and clusters and is susceptible to matrix effects such that quantitative results are possible only with careful calibration and consistent composition (Cziczo et al., 2001).

Biological aerosols have been studied with SPMS, in particular the aerosol time-of-flight mass spectrometer (ATOFMS; Cahill et al., 2015; Creamean et al., 2013; Fergenson et al., 2004; Pratt et al., 2009b). A property of SPMS bioaerosol spectra that has been exploited for their detection is the presence of phosphate $\left(\mathrm{PO}^{-}, \mathrm{PO}_{2}^{-}, \mathrm{PO}_{3}^{-}\right)$and organic nitrogen ions $\left(\mathrm{CN}^{-}, \mathrm{CNO}^{-}\right)$(Cahill et al., 2015; Fergenson et al., 2004). Those ions have also previously been shown to be present in nonbiological particles with the same instrument, however, such as vehicular exhaust (Sodeman et al., 2005) and soil dust (Silva et al., 2000). Particles that contain phosphates, organic nitrates and silicates have historically been classified as mixtures of bioaerosol and dust (Creamean et al., 2013). This work examines the prevalence of these ions in the context of spectra collected with PALMS.

Phosphorus was chosen as the focus of this paper because of its abundance in spectra of bioaerosol but also because it does not undergo gas-phase partitioning in the atmosphere (Mahowald et al., 2008). Therefore, the presence of phosphorus on a particle can often constrain its source, and only the classes of particles that are most likely to contain phosphorus are examined here. Emission estimates qualitatively agree that mineral dust, combustion products and biological particles constitute the principal phosphate emission sources. The global phosphorus budget has been modeled by Mahowald et al. (2008), indicating that $82 \%$ of the total burden is emitted in the form of mineral dust. Bioaerosol accounts for $12 \%$ and anthropogenic combustion sources, including fossil fuels, biofuels and biomass burning, account for $5 \%$ (Mahowald et al., 2008). Recently, Wang et al. (2014) provided a higher estimate of phosphorus emissions from anthropogenic combustion sources: $31 \%$. In this estimate, mineral dust was responsible for $27 \%$, bioaerosol for $17 \%$ and natural combustion sources for $20 \%$ of total phosphorus emissions (Wang et al., 2014).

In this work, calcium-phosphate-rich minerals (apatite and monazite) and fly ash are chosen to represent dust and industrial combustion particle classes, respectively. In atmospheric particles, the composition can be mixed, containing some phosphate from inorganic sources, such as calcium phosphate, and some phosphate from microbes. For instance, soils can contain minerals, live microbes and biogenic 


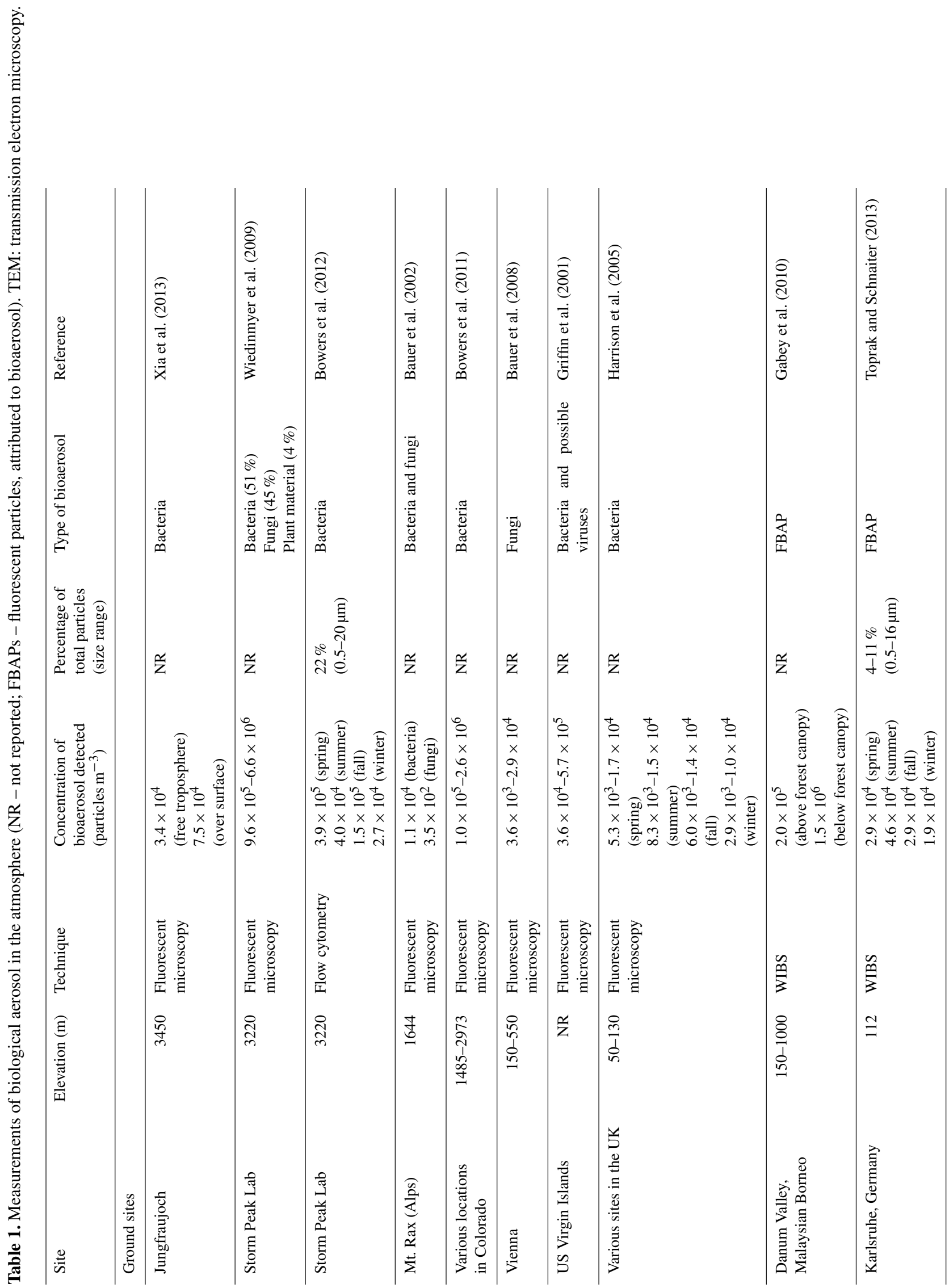




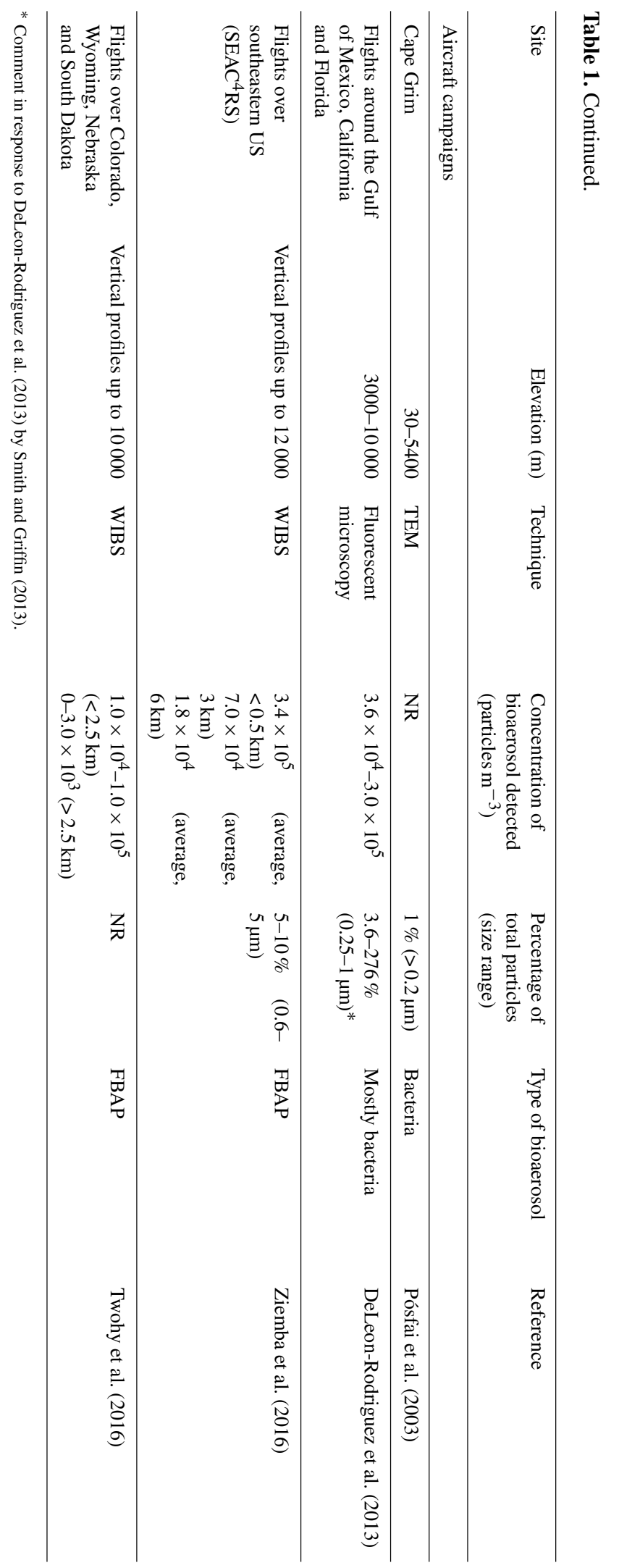

matter at all stages of decomposition. Therefore, classifying soil-derived particles with a binary biological-nonbiological classifier has uncertainties. These uncertainties are quantified here for soils using soil samples collected in various locations.

In this work, the presence of phosphorus in a mass spectrum is evaluated as a proxy for bioaerosol. All biological cells contain phosphorus because it is a component of nucleic acids and cell membranes. Distinguishing the specific mass spectral phosphate signature of biological cells from other nonbiological phosphorus is the topic of the analysis in this paper. The goal of this paper is to develop a method that can differentiate PALMS bioaerosol spectra from spectra of dust and combustion by-products.

\section{Experimental setup}

The objective of this work is to describe and validate a new SPMS-based data analysis technique that allows for the selective measurement of bioaerosol. A dataset of bioaerosol, phosphate-rich mineral and coal fly ash single-particle spectra - the three largest sources of phosphorus in atmospheric aerosols - was used to derive a classification algorithm for biological and nonbiological phosphate-containing material. This classifier was then applied to an ambient dataset collected at the Storm Peak Laboratory during the Fifth Ice Nucleation workshop, phase 3 (FIN03).

\subsection{PALMS}

The NOAA PALMS instrument has been discussed in detail elsewhere (Cziczo et al., 2006; Thomson et al., 2000). Currently, there are two copies of the PALMS instrument, both of which were used in this work. The laboratory PALMS is a prototype for the flight PALMS, which is more compact and can be deployed unattended at field sites and on aircraft (Thomson et al., 2000). Briefly, PALMS uses an aerodynamic lens to sample aerosols and impart them with a sizedependent velocity (Zhang et al., 2002, 2004). Aerodynamic particle diameter is measured by timing the particles between two continuous-wave laser beams $(532 \mathrm{~nm} \mathrm{Nd}$ : YAG in laboratory PALMS and $405 \mathrm{~nm}$ diode in flight PALMS). The particles are ablated and ionized in one step by a $193 \mathrm{~nm}$ excimer laser. A unipolar reflectron time-of-flight mass spectrometer is then used to acquire mass spectra. PALMS acquires spectra in either positive or negative polarity, but not simultaneously. For field datasets presented in this paper, sampling polarity was switched every $5 \mathrm{~min}$ for FIN03 and every $30 \mathrm{~min}$ for the Carbonaceous Aerosol and Radiative Effects Study (CARES).

Due to the high laser fluence used for desorption and ionization $\left(\sim 10^{9} \mathrm{~W} \mathrm{~cm}^{-2}\right)$, PALMS spectra show both atomic ions and ion clusters, which complicate spectral interpretation. SPMS is considered a semiquantitative technique be- 
cause the ion signal depends on the abundance and ionization potential of the substance rather than solely on its abundance (Murphy, 2007). Additionally, the ion signals can depend on the overall chemical composition of the particle, known as matrix effects (Murphy, 2007). The lower particle size threshold for PALMS is $\sim 200 \mathrm{~nm}$ diameter and is set by the amount of detectable scattered light. The upper size threshold is set by transmission in the aerodynamic lens at $\sim 3 \mu \mathrm{m}$ diameter (Cziczo et al., 2006). In PALMS, Particles toward the larger end of this size range are transmitted into the laser beam more efficiently than smaller particles. The $193 \mathrm{~nm}$ excimer laser can ionize all atmospherically relevant particles within this size range with a little detection bias (Murphy, 2007). The ionization region is identical in the laboratory and flight PALMS instruments. Raw PALMS spectra are processed using a custom IDL software. Mass peak intensities used in this paper refer to integrated peak areas normalized by the total ion current.

\subsection{Aerosol standards}

Table 2 shows numbers of negative spectra for all analyses in this paper. A portion of the data from each of the bioaerosol and nonbiological phosphate samples was used as "training data" to build the classification algorithm. The remaining test data were classified using the trained algorithm.

\subsubsection{Training dataset}

A collection of phosphorus-containing samples of biological and inorganic origin were used to train the classification algorithm used in this work. Some of the samples were analyzed with the laboratory PALMS at the Aerosol Interaction and Dynamics in the Atmosphere (AIDA) facility at Karlsruhe Institute of Technology (KIT) during the Fifth International Ice Nucleation Workshop, phase 1 (FIN01), with the remainder sampled at MIT.

Biological aerosol sampled at AIDA included two aerosolized cultures of Pseudomonas syringae bacteria, Snomax (Snomax International, Denver, CO) (irradiated, desiccated and ground Pseudomonas syringae) and hazelnut pollen wash water. The Snomax and $P$. syringae cultures were suspended in water and aerosolized with a Collisontype atomizer. The growth medium for $P$. syringae cultures was Pseudomonas Agar Base (CM0559, Oxoid Microbiology Products, Hampshire, UK).

Biological aerosol sampled at MIT included giant ragweed (Ambrosia trifida) pollen, oak (Quercus rubra) pollen, European white birch (Betula pendula) pollen, Fusarium solani spores and yeast. Samples of dried pollens and F. solani spores were purchased from Greer (Lenoir, NC). Information supplied by the manufacturer indicates that $F$. solani fungus was grown on enriched trypticase growth medium and killed with acetone prior to harvesting the spores. Ragweed and oak pollen originated from wild plants, while the birch pollen
Table 2. Summary of particle statistics for samples used to both train and test the classifier.

\begin{tabular}{|c|c|c|}
\hline Category & $\begin{array}{r}\text { Total } \\
\text { negative } \\
\text { spectra }\end{array}$ & $\begin{array}{l}\text { Used for } \\
\text { training the } \\
\text { classifier }\end{array}$ \\
\hline Bare apatite & 338 & 135 \\
\hline Processed apatite $(\sim 0.1 \mathrm{~mL})$ & 994 & 359 \\
\hline Processed apatite $(\sim 1 \mathrm{~mL})$ & 987 & 203 \\
\hline Fertilized soil dusts & 1953 & 1774 \\
\hline Fly ash & 3986 & 3536 \\
\hline Processed fly ash $(\sim 0.1 \mathrm{~mL})$ & 824 & 312 \\
\hline Monazite & 415 & 371 \\
\hline P. syringae & 1429 & 1429 \\
\hline Snomax & 497 & 497 \\
\hline F. solani (whole) & 1053 & 1010 \\
\hline F. solani (fragmented) & 1129 & 1127 \\
\hline Yeast & 778 & 757 \\
\hline Birch pollen & 1136 & 1137 \\
\hline Hazelnut pollen & 183 & 183 \\
\hline Oak pollen & 1193 & 1191 \\
\hline Ragweed pollen & 1207 & 1187 \\
\hline Bächli soil dust & 501 & Not used \\
\hline Moroccan soil dust & 460 & Not used \\
\hline Ethiopian soil dust & 502 & Not used \\
\hline Storm Peak Lab dust & 464 & Not used \\
\hline Argentinian soil dust & 507 & Not used \\
\hline Chinese soil dust & 1002 & Not used \\
\hline Saudi Arabian soil dust & 3131 & Not used \\
\hline Illite NX (dry-generated) & 1002 & Not used \\
\hline Illite NX (wet-generated) & 1030 & Not used \\
\hline Illite NX/F. solani mixed & 1396 & Not used \\
\hline FIN03 ambient sampling & 26019 & Not used \\
\hline CARES ambient sampling & 19011 & Not used \\
\hline
\end{tabular}

originated from a cultivated plant. Pollen was collected, mechanically sieved and dried. The yeast used in this experiment was commercial active dry yeast (Star Market brand). The yeast powder was sampled by PALMS from a vial subjected to slight manual agitation. Pollen grains were too large (18.9-37.9 $\mu \mathrm{m}$ according to manufacturer's specification) to sample with PALMS. They were suspended in ultrapure water $(18.2 \mathrm{M} \Omega \mathrm{cm}$, Millipore, Bedford, MA), and the suspensions were sonicated in an ultrasonic bath for $\sim 30 \mathrm{~min}$ to break up the grains. Large material was allowed to settle to the bottom, and a few drops of the clear solution from the top of the suspensions were further dissolved in ultrapure water, and the resulting solutions were aerosolized with a disposable medical nebulizer (Briggs Healthcare, Waukegan, IL). A diffusion dryer was used to remove condensed-phase water prior to sampling with PALMS. F. solani spores were sampled in two different ways: (1) dry and unprocessed, in the same way as the yeast, and (2) fragmented in an ultrasonic bath and wet-generated, in the same way as pollen samples. Examination of PALMS spectra revealed no changes in chemistry resulting from different processing methods. 
Samples of fly ash from four coal-fired US power plants were used as a proxy for combustion aerosol: J. Robert Welsh Power Plant (Mount Pleasant, TX), Joppa Power Station (Joppa, IL), Clifty Creek Power Plant (Madison, IN) and Miami Fort Generating Station (Miami Fort, $\mathrm{OH}$ ). The samples were obtained from a commercial fly ash supplier (Fly Ash Direct, Cincinnati, $\mathrm{OH})$. Fly ash was dry-generated with the shaker.

Apatite and monazite-Ce mineral samples were generated from $\sim 7.5 \mathrm{~cm}$ pieces of rock. The rocks were ground and the samples aerosolized with the shaker. Both apatite and monazite were sampled and processed at MIT. The apatite rock was contributed by Adam Sarafian (Woods Hole Oceanographic Institution, Woods Hole, MA).

Two samples of German soil were used as an example of agricultural soil that was known to be fertilized with inorganic phosphate. These were also sampled at the AIDA facility during FIN01. Note that while all other soil samples are used as test aerosols for a completed classifier, those two in particular are used in the training set to account for the presence of inorganic fertilizer.

Samples of apatite and J. Robert Welsh Power Plant fly ash were also subjected to processing with nitric acid to approximate atmospheric aging. Powdered sample was aerosolized from the shaker to fill a $9 \mathrm{~L}$ glass mixing volume. A hot plate below the volume was used to heat the air inside to $31^{\circ} \mathrm{C}$, measured in the center of the volume with a thermocouple. PALMS sampled at a flow rate of 0.44 slpm (STP (standard temperature and pressure): $0{ }^{\circ} \mathrm{C}, 1 \mathrm{~atm}$ ) from the $9 \mathrm{~L}$ volume. This constituted unprocessed aerosol. Then, $80 \% \mathrm{HNO}_{3}$ was placed with a Pasteur pipette at the heated bottom of the mixing volume. Two experiments were conducted: for experiments using $0.1 \mathrm{~mL}$ of nitric acid, the entire volume of $\mathrm{HNO}_{3}$ evaporated, producing an estimated partial pressure of about $0.005 \mathrm{~atm}$ in a static situation. In $1 \mathrm{~mL}$ experiments some liquid $\mathrm{HNO}_{3}$ remained at the bottom of the volume with an estimated partial pressure of $\mathrm{HNO}_{3}$ of $0.04 \mathrm{~atm}$. The aerosol and gas-phase $\mathrm{HNO}_{3}$ were allowed to interact for $2 \mathrm{~min}$, at which point PALMS began sampling from the volume.

\subsubsection{Test dataset}

Samples of natural soil dust were collected from various locations listed in Table 3. Five samples were investigated at the AIDA facility during FIN01 (Bächli soil, Argentina soil, Ethiopian soil, Moroccan soil and Chinese soil) with the remaining analysis at MIT (Storm Peak and Saudi Arabian soil).

Internally mixed biological-mineral particles were also analyzed at MIT. Illite NX (Clay Mineral Society) without bioaerosol was sampled dry, using a shaker (Garimella et al., 2014), and wet-generated, using a medical nebulizer containing ultrapure water. A second disposable medical nebulizer was then used to aerosolize a suspension of illite $\mathrm{NX}$ and $F$. solani spore fragments. This wet-generated aerosol was also dried with a diffusion dryer prior to PALMS sampling.

\subsection{Statistical analysis}

A support vector machine (SVM), a supervised machine learning algorithm (Cortes and Vapnik, 1995), was used as the statistical analysis method for analysis of these data. In this case a nonlinear binary classifier was constructed, using nonlinear kernel functions (Ben-Hur et al., 2001; Cortes and Vapnik, 1995). A Gaussian radial basis function kernel was empirically determined to provide the best performance in this case. For this work, the SVM algorithm was implemented in MATLAB 2016a (MathWorks, Natick, MA) using the Statistics and Machine Learning toolbox.

\subsection{Field data}

The method was employed on two ambient datasets: one acquired at the Desert Research Institute's (DRI's) Storm Peak Laboratory located in Steamboat Springs, CO, and the other acquired at the Cool, CA, site during the CARES study. Storm Peak Laboratory is located on Mt. Werner at $3220 \mathrm{~m}$ elevation at $106.74^{\circ} \mathrm{W}, 40.45^{\circ} \mathrm{N}$. This high-altitude site is often in free-tropospheric air, mainly during overnight hours, with minimal local sources (Borys and Wetzel, 1997). Ambient air was sampled using the Storm Peak facility inlet with the flight PALMS instrument in September 2015. Measurements were made during the Fifth International Ice Nucleation Workshop, phase 3 (FIN03). The measurements were carried out between 14 and 27 September 2015.

The CARES study was carried out in the summer of 2010 and included the deployment of instruments at two different ground sites: one urban (Sacramento, CA) and another in the Sierra Nevada foothills area rich in biogenic emissions (Cool, CA, site) (Zaveri et al., 2012). Thermally driven winds tend to transport the urban plume into the Sierra Nevada foothills and sometimes back again into the Sacramento area (Zaveri et al., 2012). The laboratory PALMS instrument was deployed at the Cool, CA, site at $450 \mathrm{~m}$ elevation at $121.02^{\circ} \mathrm{W}$, $38.87^{\circ} \mathrm{N}$ in a trailer throughout the campaign. It sampled ambient air between 4 and 24 June 2010 .

\section{Results}

Figure 1 shows the spectra of biological species: P. syringae bacteria, Snomax and hazelnut pollen wash water particles. These particles contain both organic and inorganic compounds. Because they are easy to ionize, the inorganic ions sodium and potassium stand out in the positive spectra despite their minor fraction by mass. Sulfates, phosphates and nitrates are present, and visible in their associations with potassium. Negative spectra are dominated by $\mathrm{CN}^{-}, \mathrm{CNO}^{-}$, phosphate $\left(\mathrm{PO}_{2}^{-}\right.$and $\left.\mathrm{PO}_{3}^{-}\right)$and sulfate $\left(\mathrm{HSO}_{4}^{-}\right)$. Higher mass associations of potassium, sulfates, phosphates and nitrates 
Table 3. Soil dust samples used in this work. The last column shows the results of analysis with the SVM classifier developed here as a percentage of negative spectra acquired.

\begin{tabular}{llll}
\hline Sample & Site description & $\begin{array}{c}\text { Approx. } \\
\text { collection } \\
\text { coordinates }\end{array}$ & $\begin{array}{r}\text { Percentage } \\
\text { biological } \\
\text { particles }\end{array}$ \\
\hline Bächli & $\begin{array}{l}\text { Outflow } \\
\text { sediment of a glacier in a feldspar-rich granitic } \\
\text { environment. No vegetation. }\end{array}$ & 6.0 \\
\hline Morocco & $\begin{array}{l}\text { Rock desert with vegetation. Close proximity to }, 8.3^{\circ} \mathrm{E} \\
\text { a road. }\end{array}$ & $33.2^{\circ} \mathrm{N}, 2.0^{\circ} \mathrm{W}$ & 20.4 \\
\hline Ethiopia & $\begin{array}{l}\text { Collected in Lake Shala National Park from a } \\
\text { region between two lakes. Area vegetated by } \\
\text { shrubs and acacia trees. }\end{array}$ & $7.5^{\circ} \mathrm{N}, 38.7^{\circ} \mathrm{E}$ & 32.1 \\
\hline Storm Peak Lab & $\begin{array}{l}\text { Collected near Storm Peak Lab. Grass and } \\
\text { shrubs present. }\end{array}$ & $40.5^{\circ} \mathrm{N}, 106.7^{\circ} \mathrm{W}$ & 31.3 \\
\hline Argentina & $\begin{array}{l}\text { La Pampa province. Top soil collected from } \\
\text { arable land with sandy loam (Steinke et al., } \\
\text { 2016). }\end{array}$ & $37^{\circ} \mathrm{S}, 64^{\circ} \mathrm{W}$ \\
\hline China/Inner Mongolia & $\begin{array}{l}\text { Xilingele steppe. Top soil collected from a pas- } \\
\text { ture with loam (Steinke et al., 2016). }\end{array}$ & $44^{\circ} \mathrm{N}, 117^{\circ} \mathrm{E}$ \\
\hline Saudi Arabia & $\begin{array}{l}\text { Various samples from several locations. Arid, } \\
\text { sandy soils. }\end{array}$ & $24.6-26.3^{\circ} \mathrm{N}, 46.1-49.6^{\circ} \mathrm{E}$ \\
\hline
\end{tabular}

occur $\left(\mathrm{K}_{3} \mathrm{H}_{2} \mathrm{SO}_{3}^{-}, \mathrm{K}_{2} \mathrm{H}_{3} \mathrm{NO}_{4}^{-}, \mathrm{K}_{3} \mathrm{H}_{2} \mathrm{PO}_{2}^{-}\right.$and $\left.\mathrm{K}_{3} \mathrm{H}_{3} \mathrm{SO}_{3}^{-}\right)$. Chlorine is present on some particles. Chlorine is a known contaminant from the agar growth medium since spectra of aerosolized agar devoid of bacteria contain large amounts of chlorine (not shown here).

Figure 2 shows spectra of apatite. In positive polarity, apatite spectra are dominated by calcium, its oxides and associations with phosphate $\left(\mathrm{CaPO}^{+}, \mathrm{CaPO}_{2}^{+}, \mathrm{CaPO}_{3}^{+}, \mathrm{Ca}_{2} \mathrm{PO}_{3}^{+}\right.$ and $\left.\mathrm{Ca}_{2} \mathrm{PO}_{4}^{+}\right)$and fluorine $\left(\mathrm{CaF}^{+}, \mathrm{Ca}_{2} \mathrm{OF}^{+}\right.$and $\left.\mathrm{Ca}_{3} \mathrm{OF}^{+}\right)$. Negative spectra are dominated by phosphates $\left(\mathrm{PO}^{-}, \mathrm{PO}_{2}^{-}\right.$ and $\mathrm{PO}_{3}^{-}$), and fluorine is often present. Lab-generated apatite spectra analyzed in this study contain little organic matter. This may be a result of the post-processing of the apatite sample, in particular of the use of ethanol as a grinding lubricant. In contrast, ethanol was not used in grinding the monazite sample here, and its spectra exhibit peaks associated with organic matter $\left(\mathrm{C}_{2} \mathrm{H}^{-}\right)$.

Figure 3 shows spectra of coal fly ash from the J. Robert Welsh Power Plant. The positive spectra contain sodium, aluminum, calcium, iron, strontium, barium and lead. As in apatite, calcium-oxygen, calcium-phosphate and calciumfluorine fragments are present. Fly ash particles also contain sulfate $\left(\mathrm{H}_{3} \mathrm{SO}_{3}^{+}\right)$. The negative spectra contain phosphates $\left(\mathrm{PO}_{2}^{-}, \mathrm{PO}_{3}^{-}\right)$, sulfates $\left(\mathrm{HSO}_{4}^{-}\right)$and silicate fragments, such as $\left(\mathrm{SiO}_{2}\right)_{2}^{-},\left(\mathrm{SiO}_{2}\right)_{2} \mathrm{O}^{-},\left(\mathrm{SiO}_{2}\right)_{2} \mathrm{Si}^{-}$and $\left(\mathrm{SiO}_{2}\right)_{3}^{-}$.

The results of $\mathrm{HNO}_{3}$ processing experiments are also shown in Figs. 2 and 3. The processing with nitric acid had an effect on both apatite and fly ash: the calcium-fluorine positive markers $\left(\mathrm{CaF}^{+}, \mathrm{Ca}_{2} \mathrm{OF}^{+}\right.$and $\left.\mathrm{Ca}_{3} \mathrm{OF}^{+}\right)$and the negative fluorine marker $\left(\mathrm{F}^{-}\right)$are either reduced in intensity or completely absent after processing. Additionally, $\mathrm{CN}^{-}$and $\mathrm{CNO}^{-}$appear and/or intensify after processing.

A classifier was designed to use the ratios of phosphate $\left(\mathrm{PO}_{2}^{-}, \mathrm{PO}_{3}^{-}\right)$and organic nitrogen $\left(\mathrm{CN}^{-}, \mathrm{CNO}^{-}\right)$spectral peaks. Those spectral peaks were used for several reasons: (1) they are clearly visible in all biological spectra that were acquired as a part of this study (Fig. 1); (2) they were used to distinguish bioaerosol from other species in previous studies (Creamean et al., 2013; Pratt et al., 2009b); and (3) sources of phosphorus on aerosol particles are well-defined and documented in the literature (Mahowald et al., 2008). The only requirement for this analysis was that each spectrum used in the training set contains both phosphate and organic nitrogen (otherwise the ratios used here become undefined). This was ensured by selecting spectra, where $\mathrm{PO}_{2}^{-}>0.001$ and $\mathrm{CNO}^{-}>0.001$. Nearly all biological spectra in the training set satisfied this criterion (Table 2). Figure 4a shows normalized histograms of the $\mathrm{PO}_{3}^{-} / \mathrm{PO}_{2}^{-}$ratio for the laboratory aerosol. The aerosols that contain only inorganic phosphorus, such as apatite, monazite and fly ash cluster at $\mathrm{PO}_{3}^{-} / \mathrm{PO}_{2}^{-}$ less than 4 and often less than 2 . The bioaerosols cluster at $\mathrm{PO}_{3}^{-} / \mathrm{PO}_{2}^{-}$greater than 2 and often greater than 4 . Ragweed pollen is an exception, with a wide cluster in $\mathrm{PO}_{3}^{-} / \mathrm{PO}_{2}^{-}$ from 1 to 5 . The processing of apatite with nitric acid tends 

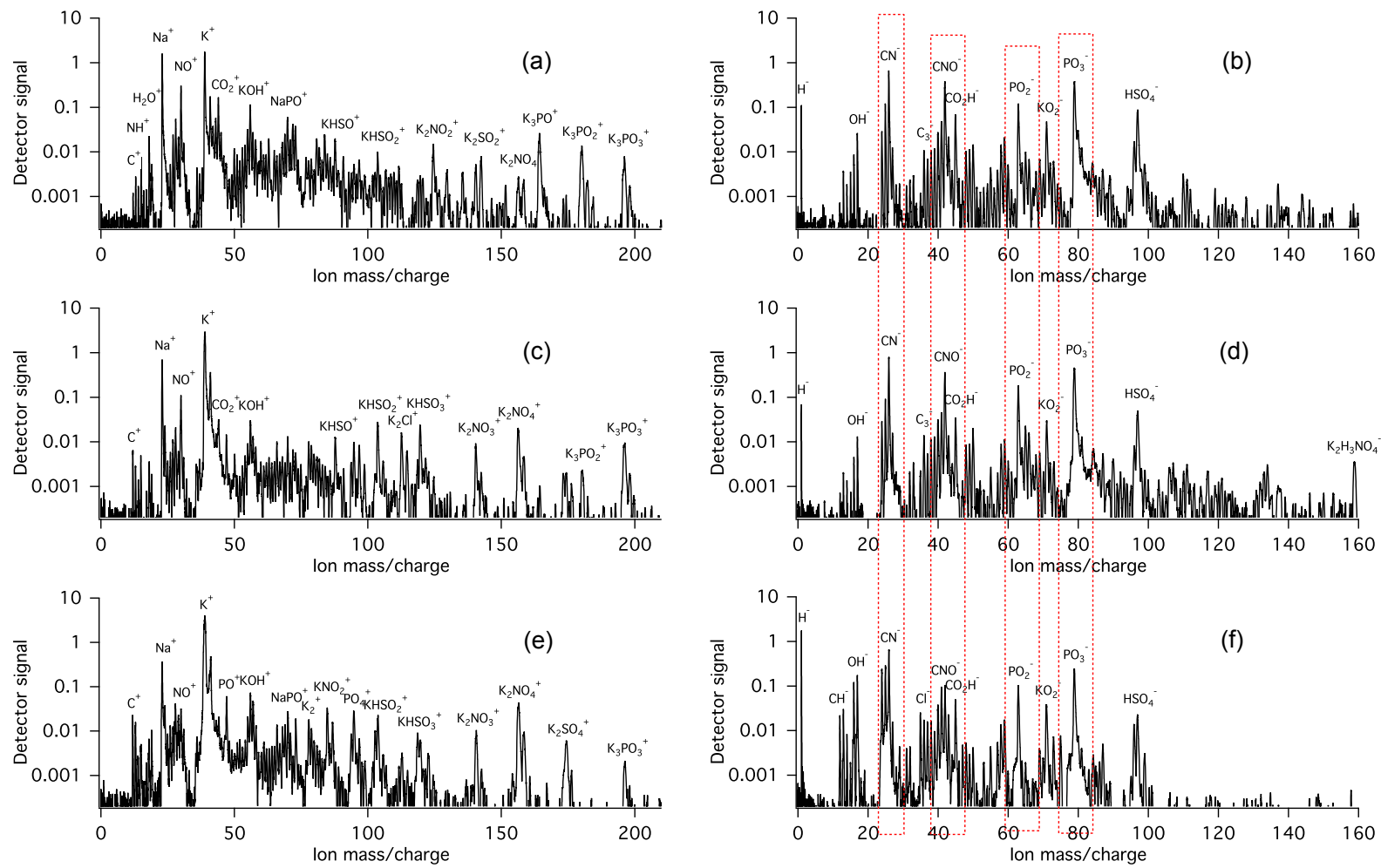

Figure 1. Representative PALMS spectra of bioaerosol. (a, b) Snomax. (c, d) P. syringae. (e, f) Hazelnut wash water. Right and left columns are positive and negative polarity, respectively. Red dotted lines are features indicated in the literature as markers for biological material.

to shift the $\mathrm{PO}_{3}^{-} / \mathrm{PO}_{2}^{-}$ratio to larger values, decreasing the disparity from the bioaerosols. Soil dusts are shown in Fig. 4, even though they are not used as training aerosol; their histogram shows a broad distribution with a tail extending into the $\mathrm{PO}_{3}^{-} / \mathrm{PO}_{2}^{-}>2$ region, indicating a mixed inorganicbiological composition. In comparison, fertilized soil dusts show a similar distribution to apatite $\left(\mathrm{PO}_{3}^{-} / \mathrm{PO}_{2}^{-}<4\right)$ due to the presence of inorganic fertilizer, which is calcium phosphate.

The SVM algorithm was used here to optimize boundaries between clusters. To do this, the algorithm needs a training dataset, where the classes are known a priori. In this paper, the training dataset is defined in Table 2. Once an optimized boundary is drawn, some of the training data can still fall on the incorrect side of the boundary when the clusters are not perfectly separable. Accuracy here is defined as the percentage of correctly classified particles in the training set once the optimized boundary is found. A simple 1-D classifier can be made based only on the ratio of phosphate peaks $\mathrm{PO}_{3}^{-} / \mathrm{PO}_{2}^{-}$greater or less than 3 . The accuracy of this simple filter is $70-80 \%$ for the materials considered here, with ragweed pollen and fly ash as the greatest sources of confusion between the bioaerosol and nonbiological classes. A higher accuracy for differentiation of the bioaerosol and nonbiological classes can be achieved if the ratio of organic nitrogen peaks is also taken into account. Figure 4B shows normalized histograms of $\mathrm{CN}^{-} / \mathrm{CNO}^{-}$ratios for the test aerosol. In contrast to $\mathrm{PO}_{3}^{-} / \mathrm{PO}_{2}^{-}$ratios, $\mathrm{CN}^{-} / \mathrm{CNO}^{-}$ratios do not, by themselves, exhibit a clear difference between the classes. A superior separation is achieved when data are plotted in a $\mathrm{CN}^{-} / \mathrm{CNO}^{-}$vs. $\mathrm{PO}_{3}^{-} / \mathrm{PO}_{2}^{-}$space, as shown in Fig. 5. In this case, two clusters appear. The soil dust class was left out of the training set because it is not known a priori if and how much biological material it contains (classification of soil dusts with the SVM algorithm is discussed later). The boundary between the classes in $\mathrm{CN}^{-} / \mathrm{CNO}^{-}$vs. $\mathrm{PO}_{3}^{-} / \mathrm{PO}_{2}^{-}$space is nonlinear, as shown in Fig. 5. The accuracy in this 2-D classification is $97 \%$. As before, ragweed pollen is the cause of most errors; if it is removed from the training dataset, the accuracy increases to $99 \%$. Processed mineral dust had a smaller impact on the accuracy: removing it from the training dataset increased the accuracy to $97.5 \%$.

For every observation, a distance from the SVM boundary can be calculated (otherwise known as score). Those distances can then be converted to the probability of correct identification. An optimized function to convert scores to probabilities was found by 10 -fold cross-validation (Platt, 1999). Because in this experiment the classes are not perfectly separable, the conversion function is a sigmoid. Posterior probabilities near 0 and 1 indicate high-confidence identification. An uncertainty boundary was defined between 0.2 and 0.8. This boundary is shown in Fig. 5. Points that lie 

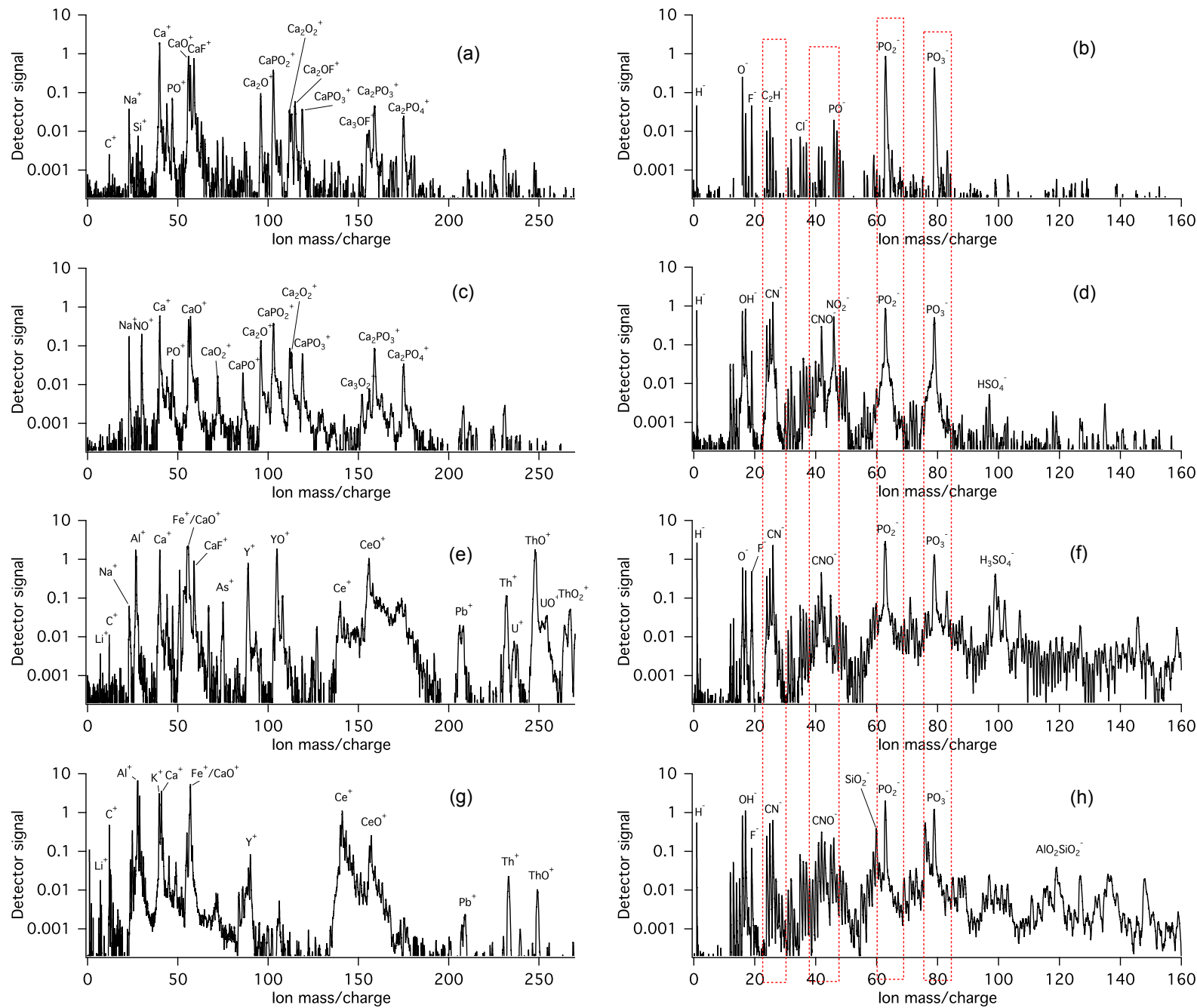

Figure 2. Representative PALMS spectra of phosphorus-rich minerals and ambient aerosol. (a, b) Unprocessed apatite. (c, d) Apatite processed with $\mathrm{HNO}_{3}$ (see text for details). (e, f) Monazite-Ce. (g, h) Ambient particles sampled at Storm Peak matching monazite chemistry. Right and left columns are positive and negative polarity, respectively. Red dotted lines are features indicated in the literature as markers for biological material.

within this boundary are marked as low-confidence assignments. Those correspond to shaded areas in Figs. 6 and 7.

Once trained with the training set, the SVM algorithm was used to analyze the FIN03 and CARES field datasets collected at Cool, CA, and Storm Peak. As a first step, "phosphorus-containing" particles were identified in both datasets. The criterion for phosphorus-containing particles used for this work is the presence of both $\mathrm{PO}_{2}^{-}$and $\mathrm{PO}_{3}^{-}$ions at fractional peak area (area of peak of interest / total spectral signal area) greater than 0.01 . This threshold was set by examination of the ambient mass spectra to determine when the phosphate peaks are distinct. Ambient particles commonly have numerous small peaks at masses below $\sim 200$ due to a diversity of organic components. The height of this background is $\sim 0.01$, and data below this level are considered uncertain. Phosphorus-containing ambient spectra were then classified by the SVM algorithm as bioaerosol or inorganic phosphorus if the $\mathrm{CNO}^{-}$ion was also present at fractional peak area greater than 0.001 . If $\mathrm{CNO}^{-}$fractional area was less than 0.001 , the spectrum was also classified as inorganic phosphorus.

During the FIN03 campaign, phosphorus-containing particles represented from 0.2 to $0.5 \%$ by number of the total detected particles in negative ion mode depending on the sampling day and a $0.4 \%$ average for the entire dataset. As shown in Fig. 6a when the binary classifier described in this work was applied to the phosphorus-containing particles, bioaerosol represented a $29 \%$ subset by number (i.e., $0.1 \%$ of total analyzed particles). During the CARES campaign, phosphorus-containing particles were 1.1 to $4.2 \%$ by number of the total particles detected in negative ion mode, with a $2.4 \%$ average for the dataset (Fig. 7a). Bioaerosol parti- 

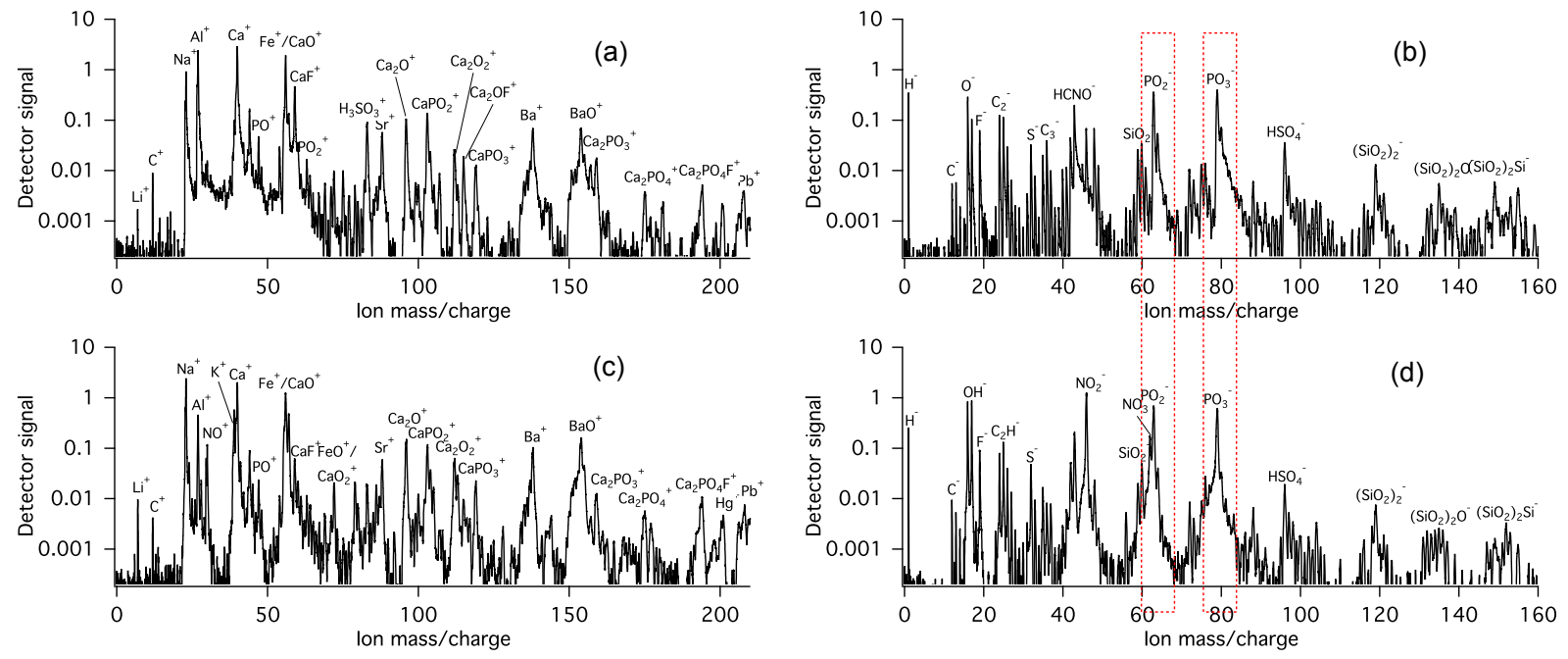

Figure 3. Representative PALMS spectra of coal fly ash from the J. Robert Welsh power plant. (a, b) Unprocessed fly ash. (c, d) Fly ash processed with $\mathrm{HNO}_{3}$ (see text for details). Right and left columns are positive and negative polarity, respectively. Red dotted lines are features indicated in the literature as markers for biological material.

cles represented a $63 \%$ subset by number (i.e., $1.2 \%$ of total analyzed particles). This range $(0.1-1.2 \%)$ is within, and towards the lower end, of previous estimates with biologicalspecific techniques (Table 1). This lower-end estimate may, in part, be due to PALMS sampling particles in the 200 $500 \mathrm{~nm}$ diameter range as well as larger sizes. Previous estimates tend to show increased bioaerosol in the supermicrometer range, and data are often unavailable for the numerous particles smaller than $500 \mathrm{~nm}$ diameter.

The origin of the nonbiological phosphate particles is likely phosphate-bearing mineral dust or fly ash. The CARES site experienced influences of aged marine, urban and local biogenic sources. Within the urban plumes, a likely source of inorganic phosphate is industrial combustion aerosol. At Storm Peak a likely source is the mining of phosphate rock and nearby monazite deposits. Figure $6 \mathrm{~b}$ shows HYSPLIT back trajectories for the 10 days of the FIN03 campaign; the air masses sampled cross deposits of either phosphate rock (apatite) or rare-earth elements (monazite or carbonatite). As examples, on 27 September the back trajectory intersects the vicinity of an active rare-earth element (REE) mine in Mountain Pass, CA, and on 18 September and 20 September the air mass intersected active phosphate mines in Idaho. Although negative spectra of apatite and monazite cannot be definitively differentiated from fly ash or soil dust spectra, positive spectra acquired during FIN03 additionally suggest that monazite-type material was present. Figure $2 \mathrm{~g}$ and $\mathrm{h}$ show nonbiological phosphate-rich ambient spectra from FIN03. Figure 2e and $\mathrm{f}$ (monazite) contain similar features and matching rare-earth elements.

In total, 56 and $36 \%$ of phosphate-containing particles analyzed in FIN03 and CARES, respectively, categorized as biological also contained silicate features. Considered in more detail in the next section, a subset of these may represent internal mixtures of biological and mineral components.

\section{Discussion}

The method of identification of bioaerosol described here is based on ratios of phosphate and organic nitrogen peaks. This work is specific to PALMS but can be considered a starting point from which identification and differentiation can be made with similar instruments. Previous work with PALMS shows this ratio approach can be used to identify differences in chemistry, for example among mineral dusts (Gallavardin et al., 2008). In this case the classes are bioaerosol and nonbiological phosphorus; Fig. 4a shows that phosphorus ionizes differently in these classes. In apatite and monazite, phosphorus occurs as calcium phosphate. In biological particles, phosphorus occurs mostly in phospholipid bilayers and nucleic acids. In these experiments, the $\mathrm{PO}_{3}^{-} / \mathrm{PO}_{2}^{-}$ratio of those two forms is different (Fig. 4a). The agricultural soils considered here cluster with the minerals and fly ash, and we assume the phosphorus is due to the use of inorganic fertilizer, which is derived from calcium phosphate (Koppelaar and Weikard, 2013). Fly ash aerosol clusters similarly to apatite and monazite but with a wider distribution; this is likely because the chemical from of phosphorus in fly ash is different than in the minerals. Phosphorus present in coal is volatilized and then condenses into different forms during the combustion process (Wang et al., 2014).

During the FIN03 campaign at Storm Peak, $0.2-0.5 \%$ of particles by number detected in negative polarity contained measureable phosphorus (Fig. 6a). On most days, the majority of phosphorus-rich particles were inorganic. Particles with positive spectra showing the characteristics of monazite 
(a)
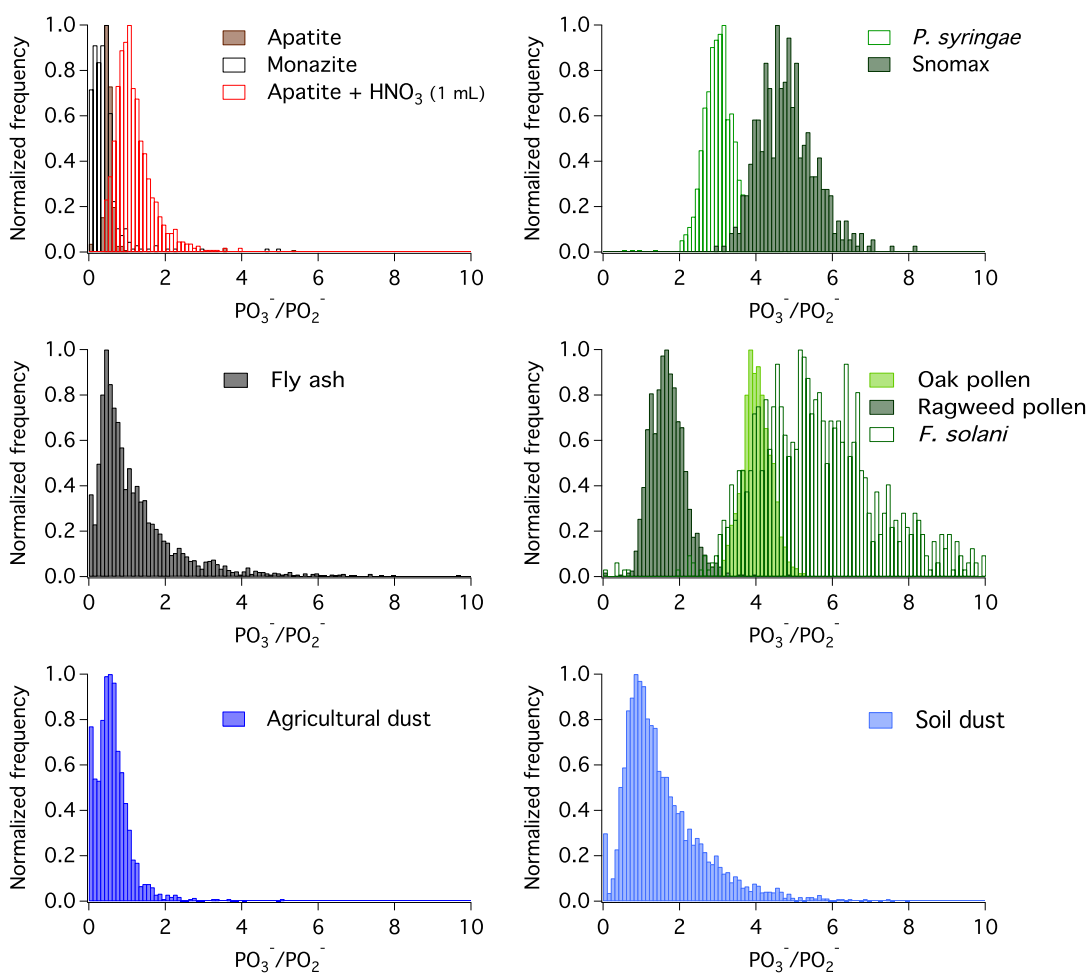

(b)
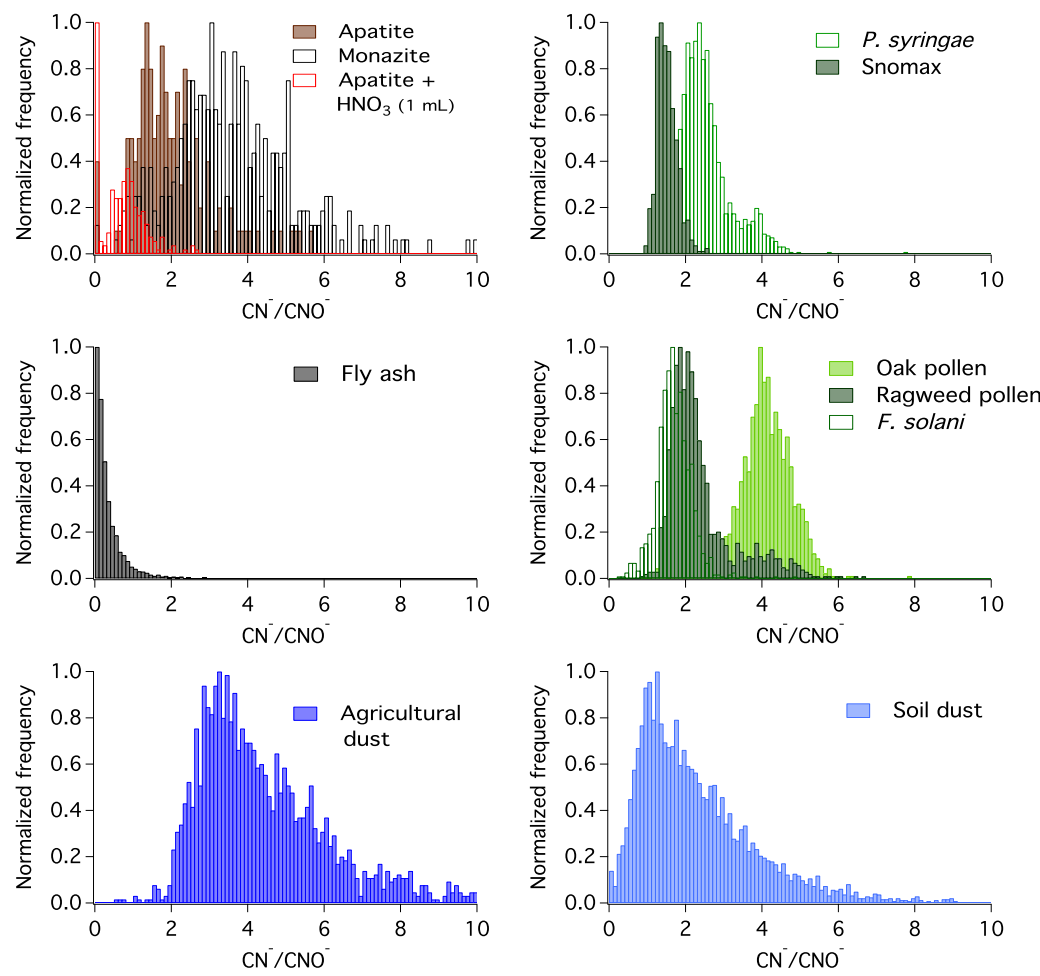

Figure 4. (a) Normalized histograms of the $\mathrm{PO}_{3}^{-} / \mathrm{PO}_{2}^{-}$ratio for the laboratory aerosol. (b) Normalized histograms of the $\mathrm{CN}^{-} / \mathrm{CNO}^{-}$ ratio for the same laboratory aerosol as in (a). Delineation between the clusters at a $\mathrm{PO}_{3}^{-} / \mathrm{PO}_{2}^{-}$ratio of 3 results in a $70-80 \%$ classification accuracy depending on the types of particles considered. Note that soil dusts were not used as part of the training dataset and that not all training aerosols are shown here for clarity. 


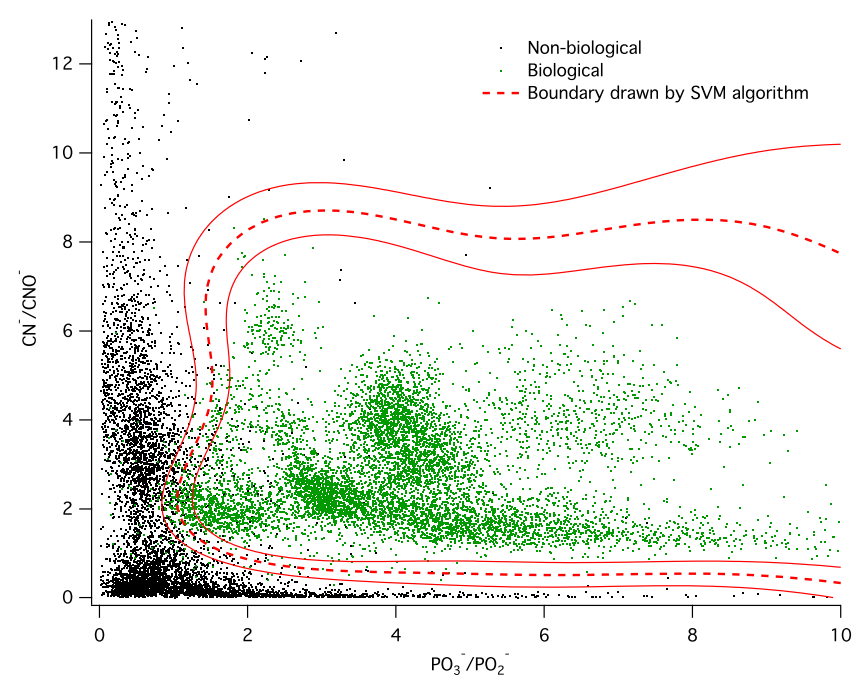

Figure 5. Inorganic and biological particle clusters in $\mathrm{CN}^{-} / \mathrm{CNO}^{-}$vs. $\mathrm{PO}_{3}^{-} / \mathrm{PO}_{2}^{-}$space. The SVM algorithm "draws" a boundary between the clusters with the red dashed line with an overall $97 \%$ classification accuracy. Solid red lines indicate the uncertainty boundary (see text for further details).

coupled to back trajectories over source areas suggest the origin of the inorganic phosphate particles. Although apatite or monazite particles make up a small portion of ambient particles at Storm Peak, they are potentially interesting not only due to their possible confusion with biological phosphate but also as a tracer for industrial mining and processing activities. Currently, such activities are taking place in Idaho and until very recently at Mountain Pass, CA (US Geological Survey, 2016a, b). Smaller exploration activities are also taking place at the Bear Lodge, WY, and the REE-rich areas in Colorado, Idaho and Montana are of interest (US Geological Survey, 2016a).

During the CARES campaign more particles contained phosphorus (1-4.2\%) and a higher percentage of phosphaterich particles were identified as biological (63\% vs. $29 \%$ in FIN03). Because the site contains strong local biogenic and urban influences, the sources of biological particles are probably local. As shown in Fig. 7b, aged marine particles were also present on many days; however, only $4 \%$ of particles identified as biological also contained markers associated with sea salts.

\subsection{Comparison with existing literature}

Previous studies have attempted to identify bioaerosol with SPMS based on the presence of phosphate and organic nitrate components. Creamean et al. (2013) and Pratt et al. (2009b) suggested a "Boolean criterion" where the existence of $\mathrm{CN}^{-}$, $\mathrm{CNO}^{-}$and $\mathrm{PO}_{3}^{-}$in a particle resulted in its classification as biological. If silicate components were additionally present, the particle was classified as an internal mixture of mineral dust and biological components (Creamean et al., 2013,
2014). Such "Boolean" criteria for particle identification, can be helpful in distinguishing aerosol types when the signatures are unique to one particle type.

The selectivity of this simple three-component filter (presence or absence of $\mathrm{CN}^{-}, \mathrm{CNO}^{-}$and $\mathrm{PO}_{3}^{-}$) for biological particles was investigated for PALMS using the test aerosol database with results shown in Fig. 8. Note that previous literature does not provide information on the thresholds used to determine the presence or absence of ions in an analysis of ATOFMS spectra. Furthermore, because of hardware differences, detection limits of PALMS and ATOFMS are known to be different (Murphy, 2007). This analysis focuses on PALMS and the threshold for "presence" was chosen as 0.001 , which was observed to be the detection limit for $\mathrm{CN}^{-}, \mathrm{CNO}^{-}$and $\mathrm{PO}_{3}^{-}$in the laboratory aerosol database used here. The simple filter successfully picks biological material. However, it also has a high rate of false positives. For the material that contains inorganic phosphorus (i.e., samples known to be devoid of biological material), the threecomponent filter selects $56 \%$ of fly ash, $56 \%$ of agricultural dust and $32 \%$ of apatite and monazite. Soil dust is identified as biological $78 \%$ of the time.

The effect of the misidentification of inorganic phosphate as biological can be considered in the context of the atmospheric abundance of the three major phosphate bearing aerosols: mineral dust, fly ash and bioaerosol (estimates given in Table 4). Because the emissions estimates vary, the highest fraction of bioaerosol is the case of the highest estimate of bioaerosol coupled to the lowest estimate of fly ash and mineral dust (Table 4 and Fig. 9a). Conversely, the lowest fraction of bioaerosol is the case of the lowest estimate of bioaerosol coupled to the highest estimate of fly ash and mineral dust (Table 4 and Fig. 9b).

The misidentification rates noted above are then propagated onto the high and low estimates. As an example, the fraction of aerosol phosphate due to fly ash (1\% in the high and $5 \%$ in the low bioaerosol estimate) is multiplied by 0.56 to indicate the fraction of fly ash that would be misidentified as biological phosphate with the simple three-component filter. This misidentification effect is repeated for the mineral dust emission rate and misidentification fraction. For simplicity, we considered the mineral dust fraction to be desert soils, termed Aridisols and Entisols, which are predominantly present in dust-productive regions, such as the Sahara or the dust bowl (Yang et al., 2013). According to Yang and Post (2011), the organic phosphate content of those soils is 5$15 \%$, but this is a second-order effect when compared to misclassification. In the high-bioaerosol scenario, $17 \%$ of the phosphate aerosol is biological (Fig. 9a), but when misidentification is considered, $81 \%$ of particles is identified as such (Fig. 9c). In the low-bioaerosol scenario, $2 \%$ of the phosphate aerosol is biological (Fig. 9b), but when misidentification is considered, $77 \%$ of the particles is identified as such (Fig. 9d). This illustrates that simplistic identification can lead to large misclassification errors of aerosol sources. 
(a)

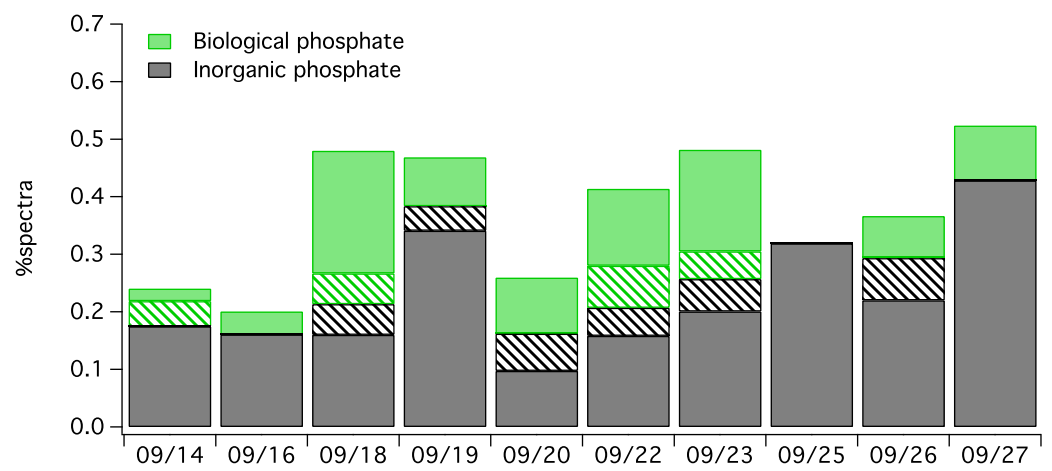

(b)

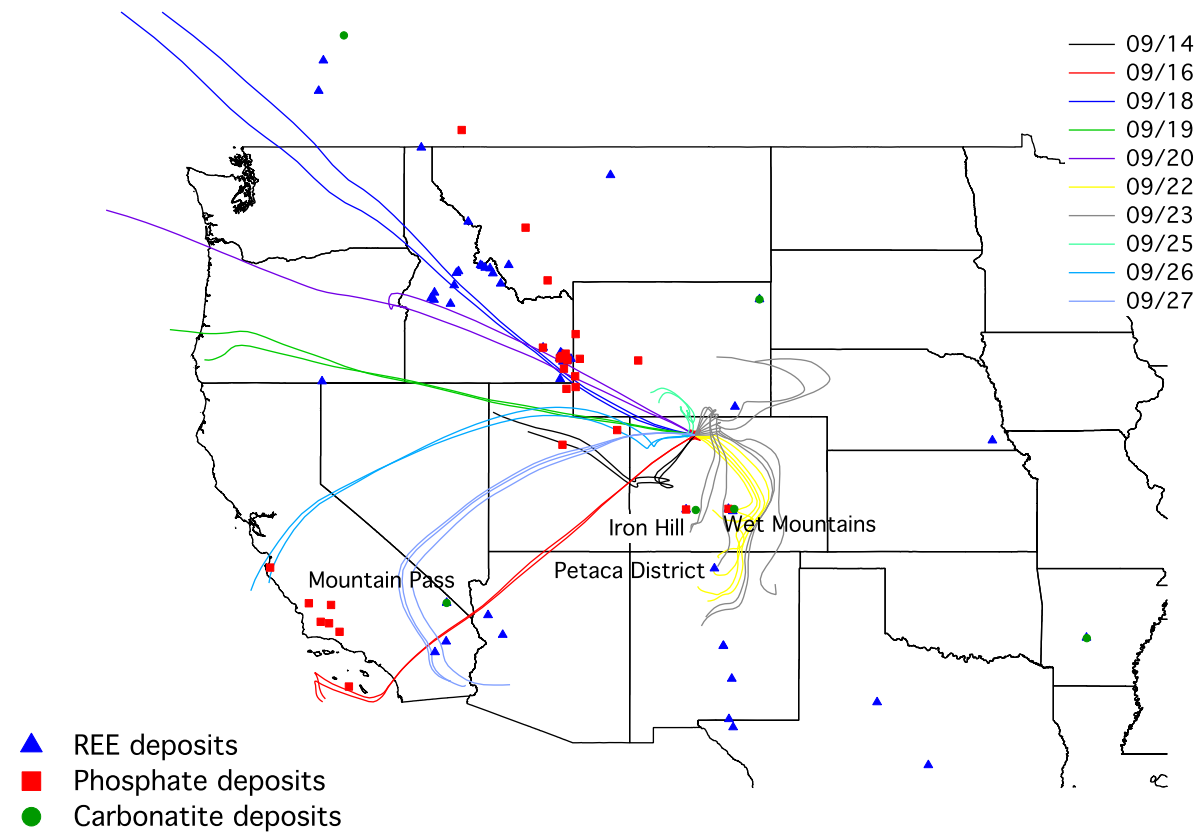

Figure 6. (a) The percentage of ambient aerosol particles from the FIN03 dataset categorized as biological and inorganic (phosphate-bearing mineral dust or fly ash) phosphate using the criteria developed in this work. Hatched regions indicate uncertain assignments as per the boundaries in Fig. 5. Note that at this location and time of year inorganic phosphate dominates biological particles. (b) HYSPLIT back trajectories plotted for 10 measurement days at Storm Peak Laboratory. Locations of REE, phosphate and carobonatite deposits, sourced from US Geological Survey, are co-plotted (Berger et al., 2009; Chernoff and Orris, 2002; Orris and Grauch, 2002). Dates are given as $\mathrm{MM} / \mathrm{DD}$

Misidentification can also lead to misattribution. Pratt et al. (2009b) analyzed ice residuals sampled in an orographic cloud and suggested a biological source using the simple three-component filter applied to spectra containing calcium, sodium, organic carbon, organic nitrogen and phosphate. The processed apatite spectrum in Fig. 2, devoid of biological material, contains all of these markers. Similar to the Storm Peak dataset, the Pratt et al. (2009b) wave cloud occurred in west-central Wyoming, which is near the Idaho phosphate rock deposits (Fig. 6), and four US states with active mining of phosphate rock for use as inorganic fertilizer in agriculture (US Geological Survey, 2016b).
As noted above, the Pratt et al. (2009b) and Creamean et al. $(2013,2014)$ studies were performed with a different SPMS, the ATOFMS (Gard et al., 1997; Pratt et al., 2009a). Because the ATOFMS uses a desorption-ionization laser of a different wavelength (266 nm), the SVM algorithm used here may not directly translate to that instrument (Murphy, 2007). Instead, the calculation above assumes only that the misidentification rates between the simple three-component filter and the SVM algorithm apply. 
(a)

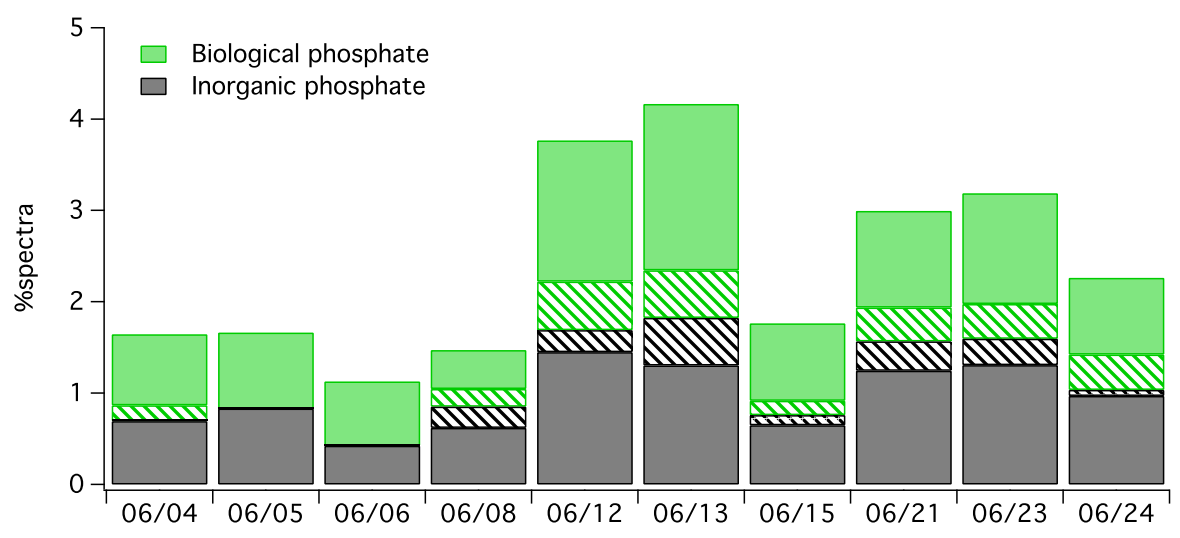

(b)

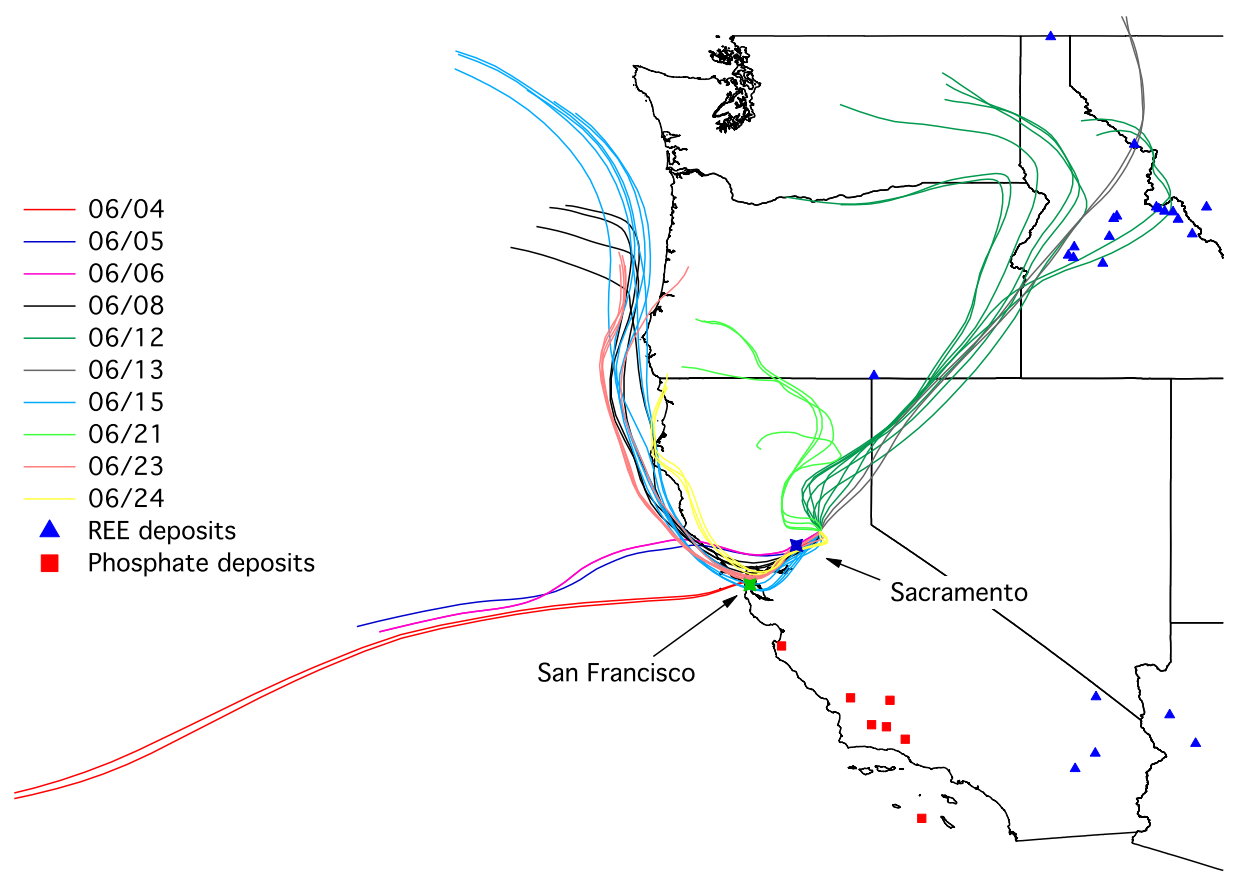

Figure 7. (a) The percentage of ambient aerosol particles from the CARES dataset categorized as biological and inorganic (phosphatebearing mineral dust or fly ash) phosphate using the criteria developed in this work. Hatched regions indicate uncertain assignments per the boundaries in Fig. 5. (b) HYSPLIT back trajectories plotted for 10 measurement days at the Cool, CA, site. Locations of REE, phosphate and carobonatite deposits, sourced from US Geological Survey, are co-plotted (Berger et al., 2009; Chernoff and Orris, 2002; Orris and Grauch, 2002) along with locations of major urban centers. Dates are given as MM/DD.

\subsection{Soil dust and internal dust-biological mixtures}

Soil dust is an important but complicated category of phosphate-containing atmospheric particles. Modeling studies, such as Mahowald et al. (2008), treat all phosphorus in soil dust aerosol as inorganic. However, the phosphorus in soil investigated here took both organic and inorganic forms. Walker and Syers (1976) proposed a conceptual model of transformations of phosphorus depending on the age of the soil. At the beginning of its development, all soil phospho- rus is bound in its primary mineral form, matching that of the parent material, which is primarily apatite (Walker and Syers, 1976; Yang and Post, 2011). As the soil ages, the primary phosphorus is released. Some of it enters the organic reservoir and is utilized by vegetation, some is adsorbed onto the surface of secondary soil minerals (non-occluded phosphorus) and then gradually encapsulated by secondary minerals ( $\mathrm{Fe}$ and $\mathrm{Al}$ oxides) into an occluded form. The total phosphorus content of the soil decreases as the soil ages, due to leaching. The organic fraction can encompass mi- 


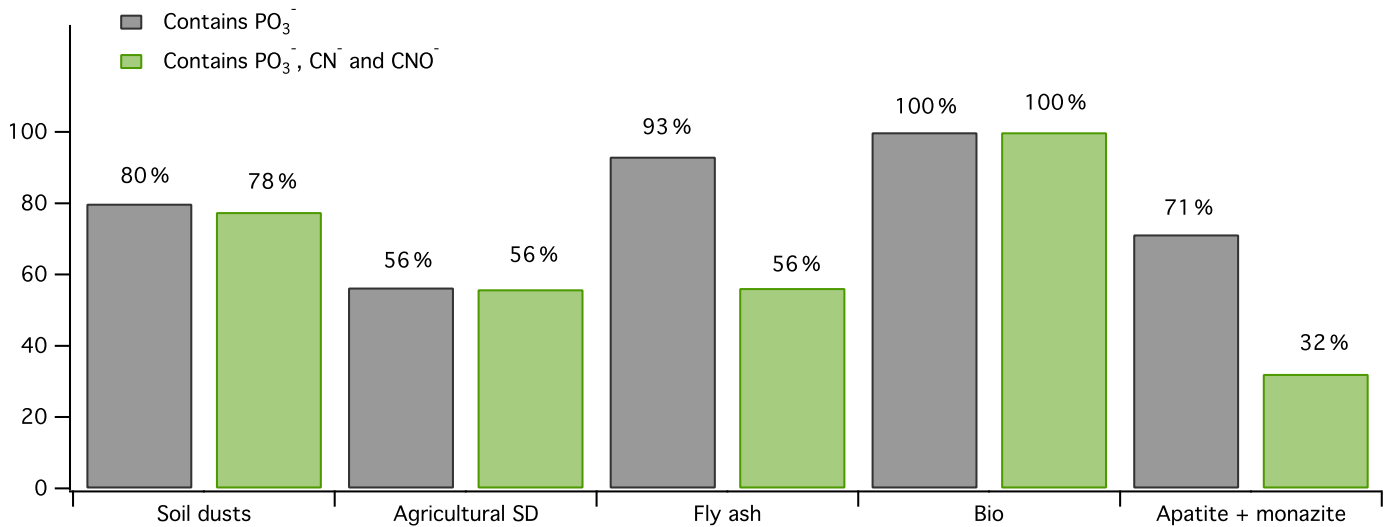

Figure 8. Percentage of particles that include $\mathrm{PO}_{3}^{-}, \mathrm{CN}^{-}$and $\mathrm{CNO}^{-}$markers in five classes of atmospherically relevant aerosol spectra acquired with PALMS in this work. Note that the green bars indicate the percentage of particles of each type identified as biological using literature criteria. In the case of bioaerosol the identification is correct. In all other aerosol classes the green bar denotes a typical level of misidentification.

(a)

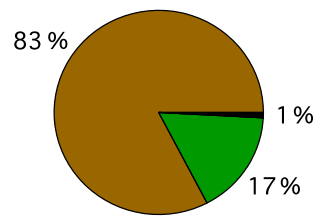

(c)

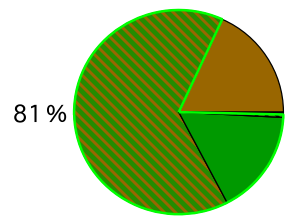

(b)

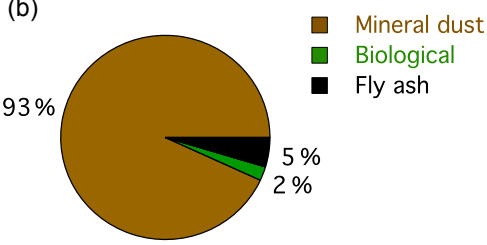

(d)

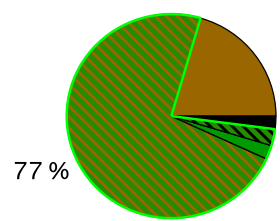

Figure 9. Abundance of bioaerosol, mineral dust and fly ash in the atmosphere constructed using emissions estimates in Table 3. (a) Highest estimate for bioaerosol coupled to lowest estimates for dust and fly ash. (b) Lowest estimate of bioaerosol in the atmosphere coupled to highest estimates for dust and fly ash. (c, d) Effect of misidentification of phosphate- and organic-nitrogen-containing aerosol as biological using the emissions in (a) and (b), respectively. The hatched regions correspond to the misidentified fractions of mineral dust and fly ash. In these estimates the correct emissions (solid green region) in (a) and (b) (17 and 2\%, respectively) are overestimated (hatched green region of misidentified aerosol plus solid green region) in (c) and (d) (as 81 and $77 \%$, respectively).

croorganisms, their metabolic by-products and other biological matter at various stages of decomposition. Soil microorganisms are the key players in converting organic phosphorus back into the mineral form (Brookes et al., 1984). Yang and Post (2011) estimated organic and inorganic phosphorus content of various soils based on available data. Spodosols (moist forest soils) have the highest fraction of organic phosphorus ( $\sim 45 \%)$, and Aridisols (sandy desert soils) have the lowest $(\sim 5 \%)$ (Yang and Post, 2011). Yang et al. (2013)

compiled a global map of soil phosphorus distribution and its forms and found that $20 \%$, on average, of total phosphorus is organic. Wang et al. (2010) arrive at $34 \%$ of soil phosphorus as organic globally.

The biological PALMS filter was applied to several soil dust samples (Table 3). As would be expected, soils collected in areas with less vegetation exhibit smaller biological contributions. We note that organic phosphorus content is not necessarily a direct indicator of microbes since it also encompasses decomposed biogenic and organic matter. At this time, we are not able to delineate between primary biological, biogenic or simply complex organic (such as humic acids) material.

In the FIN03 field dataset, $56 \%$ of particles identified as biological also contained silicate markers normally associated with mineral dust. In the CARES dataset the percentage of such particles was $36 \%$. This represents an upper limit of particles that are an internal mixture of dust and biological material. As stated in the last paragraph, this biological material probably does not consist of whole cells sitting on mineral particles; such internally mixed mineral dust particle with whole or fragments of biological material are not supported by EM (Peter Buseck, personal communication). It currently remains unclear if such internally mixed particles would be counted as biological with an optical microscope after fluorescent staining.

Internal mixtures of biological and mineral components were generated in the laboratory in order to investigate this; an exemplary spectrum of such a particle is shown in Fig. 10. The spectrum contains alumino-silicate markers consistent with mineral dust together with phosphate markers that, in this case, come from the biological material. In spectra of pure illite, no phosphate markers are present. Using the classifier developed in this paper on the laboratory-generated internally mixed particles correctly identifies the phosphate signatures to be biological. 
Table 4. Literature estimates of emission rates of primary biological particles, dust and fly ash.

\begin{tabular}{lll}
\hline Particle & \multicolumn{2}{c}{ Emissions $\left(\mathrm{Tg} \mathrm{yr}^{-1}\right)$} \\
\cline { 2 - 3 } & low estimate & high estimate \\
\hline Dust & 1490 (Zender, 2003) & 7800 (Jacobson and Streets, 2009) \\
Primary biological & 186 (Mahowald et al., 2008) & 298 (Jacobson and Streets, 2009) \\
Fly ash & 14.9 (Garimella, 2017) & $390($ Garimella, 2017) \\
\hline
\end{tabular}
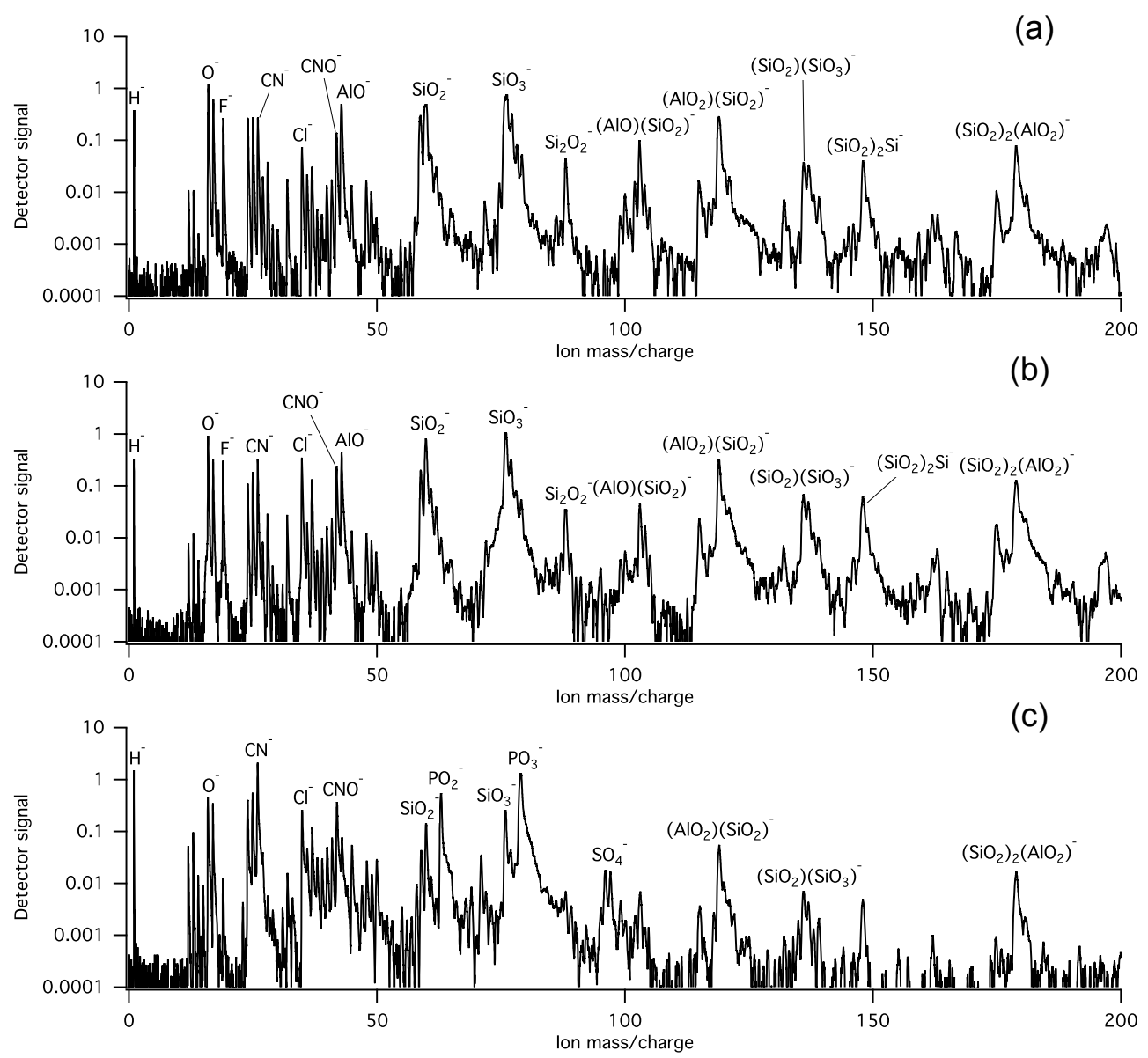

Figure 10. Exemplary PALMS negative polarity spectra of (a): dry-dispersed illite NX; (b): wet-dispersed illite NX from a distilled, deionized water slurry; (c): similarly wet-dispersed illite NX but from a water slurry that also contained $F$. solani spores. Note that phosphate features are absent in (a) and (b) but present in (c) due to the addition of biological material to the mineral dust.

\subsection{Uncertainty in bioaerosol identification in PALMS spectra}

Phosphorus peak ratios in biological particles cluster differently than in inorganic phosphorus particles with ragweed pollen being an exception (Fig. 4a). No satisfactory explanation for this observation has been found although contamination with phosphate fertilizer cannot be ruled out. The accuracy of the biological filter using $\mathrm{PO}_{3}^{-} / \mathrm{PO}_{2}^{-}$and $\mathrm{CN}^{-} / \mathrm{CNO}^{-}$ratios is $97 \%$, with ragweed alone being the source of most of the error. This unexplained behavior is a cause for concern, as the list of biological samples used as a training set is extensive but not exhaustive and other exceptions could exist.

The basic classifier presented in this paper is binary: all phosphate- and organic-nitrogen-containing particles are classified either as biological or inorganic. However, spectra whose $\mathrm{PO}_{3}^{-} / \mathrm{PO}_{2}^{-}$and $\mathrm{CN}^{-} / \mathrm{CNO}^{-}$ratios are very close to the SVM boundary have more uncertain assignments than those whose $\mathrm{PO}_{3}^{-} / \mathrm{PO}_{2}^{-}$and $\mathrm{CN}^{-} / \mathrm{CNO}^{-}$ratios fall far away from the boundary. In order to provide an additional measure of classification uncertainty, a probability bound 
was defined as shown in Fig. 5. According to this definition, $96 \%$ of particles in the training dataset were classified with high confidence (Fig. 5). In the FIN03 and CARES field datasets, $79 \%$ of phosphate-containing particles were classified with high confidence. The low-confidence assignments are shown in Figs. 6a and 7a with shaded areas. The low-confidence assignments in field datasets can be related to chemical processing of particles (either at the source like in soils or during transport) or to internal mixing of biological and inorganic phosphate.

Because soil dusts are a special category, where lines between biological and inorganic phosphorus sources can be blurry because of ongoing chemical transformations, they have higher classification uncertainties than other types of phosphate-containing aerosols. In the field data, dustbiological mixtures (defined as particles classified as biological with silicate features) are overrepresented in the lowconfidence assignments. Dust-biological mixtures constitute $26 \%$ (CARES) $-46 \%$ (FIN03) of high-confidence assignments and $64 \%$ (CARES)-68\% (FIN03) of low-confidence assignments. Moreover, only $75 \%$ of phosphate-containing soil dust particles were classified with high confidence. However, in simple two-component internal mixtures of dust and biological fragments (Fig. 10), phosphate features can be identified as biological with high confidence $(98 \%)$.

Because the field studies were performed during different time periods, it was difficult to control for a constant excimer laser fluence. However, laser fluence was similar for all laboratory samples acquired (3-5 $\mathrm{mJ}$ pulse energy). This is a possible source of uncertainty, as fragmentation patterns can differ depending on pulse energy.

\section{Conclusions}

This paper examines criteria that can be used with SPMS instruments to identify bioaerosol. We propose a new technique of bioaerosol detection and validate it using a database of phosphorus-bearing spectra. A simple binary classification scheme was optimized using an SVM algorithm, with $97 \%$ accuracy. Ambient data collected during FIN03 and CARES campaigns are then analyzed with this binary classifier. Particles with phosphorus were up to $0.5 \%$ for FIN03 and $4.2 \%$ for CARES by number of all ambient particles in the 200 $3000 \mathrm{~nm}$ size range. On average, 29\% (FIN03) and 63\% (CARES) of these particles were identified as biological.

Our work expands on previous SPMS sampling that used a more simple Boolean three-marker criterion $\left(\mathrm{CN}^{-}, \mathrm{CNO}^{-}\right.$ and $\mathrm{PO}_{3}^{-}$) to classify particles as primary biological or not (Creamean et al., 2013, 2014). We show that the presence of these markers is necessary but not sufficient. We show a false positive rate of the Boolean filter between 64 and $75 \%$ for a realistic atmospheric mixture of soil dust, fly ash and primary biological particles.
The trained SVM algorithm was also used to measure the biological content of soil dusts. Different soil dust samples can have different contents of biological material with a range from 2 to $32 \%$ observed here. Consistent with the literature, samples taken from areas with vegetation exhibit a higher biological content.

Data availability. Data used to generate the figures are included in a Harvard Dataverse dataset with the same name as this paper (Zawadowicz, 2017, https://doi.org/10.7910/DVN/C6V7FL).

Competing interests. The authors declare that they have no conflict of interest.

Acknowledgements. The authors gratefully acknowledge funding from NASA grant no. NNX13AO15G, NSF grant no. AGS1461347, NSF grant no. AGS-1339264 and DOE grant no. DE-SC0014487. M. A. Z. acknowledges the support of a NASA Earth and Space Science Fellowship. The authors would like to thank Ottmar Moehler and the KIT AIDA facility staff for hosting the FIN01 workshop and Gannet Hallar, Ian McCubbin and DRI Storm Peak Laboratory for hosting the FIN03 workshop. The authors thank the entire CARES, FIN01 and FIN03 teams for support and Peter Buseck for useful discussions.

Edited by: A. Huffman

Reviewed by: four anonymous referees

\section{References}

Amato, P., Ménager, M., Sancelme, M., Laj, P., Mailhot, G., and Delort, A.-M.: Microbial population in cloud water at the Puy de Dôme: Implications for the chemistry of clouds, Atmos. Environ., 39, 4143-4153, https://doi.org/10.1016/j.atmosenv.2005.04.002, 2005.

Amato, P., Parazols, M., Sancelme, M., Laj, P., Mailhot, G., and Delort, A.-M.: Microorganisms isolated from the water phase of tropospheric clouds at the Puy de Dôme: major groups and growth abilities at low temperatures, FEMS Microbiol. Ecol., 59, 242254, https://doi.org/10.1111/j.1574-6941.2006.00199.x, 2007.

Bauer, H., Kasper-Giebl, A., Löflund, M., Giebl, H., Hitzenberger, R., Zibuschka, F., and Puxbaum, H.: The contribution of bacteria and fungal spores to the organic carbon content of cloud water, precipitation and aerosols, Atmos. Res., 64, 109-119, https://doi.org/10.1016/S0169-8095(02)00084-4, 2002.

Bauer, H., Schueller, E., Weinke, G., Berger, A., Hitzenberger, R., Marr, I. L., and Puxbaum, H.: Significant contributions of fungal spores to the organic carbon and to the aerosol mass balance of the urban atmospheric aerosol, Atmos. Environ., 42, 5542-5549, https://doi.org/10.1016/j.atmosenv.2008.03.019, 2008.

Ben-Hur, A., Horn, D., Siegelmann, H. T., and Vapnik, V.: Support Vector Clustering, J. Mach. Learn. Res., 2, 125-137, 2001.

Berger, V. I., Singer, D. A., and Orris, G. J.: Carbonatites of the world, explored deposits of $\mathrm{Nb}$ and REE; database and grade and 
tonnage models: US Geological Survey Open-File Report 20091139, 17 pp., 2009.

Borys, R. D. and Wetzel, M. A.: Storm Peak Laboratory: A Research, Teaching, and Service Facility for the Atmospheric Sciences, Bull. Am. Meteorol. Soc., 78, 2115-2123, https://doi.org/10.1175/15200477(1997)078<2115:SPLART>2.0.CO;2, 1997.

Bowers, R. M., Lauber, C. L., Wiedinmyer, C., Hamady, M., Hallar, A. G., Fall, R., Knight, R., and Fierer, N.: Characterization of Airborne Microbial Communities at a High-Elevation Site and Their Potential To Act as Atmospheric Ice Nuclei, Appl. Environ. Microbiol., 75, 5121-5130, https://doi.org/10.1128/AEM.00447-09, 2009.

Bowers, R. M., McLetchie, S., Knight, R., and Fierer, N.: Spatial variability in airborne bacterial communities across landuse types and their relationship to the bacterial communities of potential source environments, ISME J., 5, 601-612, https://doi.org/10.1038/ismej.2010.167, 2011.

Bowers, R. M., McCubbin, I. B., Hallar, A. G., and Fierer, N.: Seasonal variability in airborne bacterial communities at a high-elevation site, Atmos. Environ., 50, 41-49, https://doi.org/10.1016/j.atmosenv.2012.01.005, 2012.

Brookes, P. C., Powlson, D. S., and Jenkinson, D. S.: Phosphorus in the soil microbial biomass, Soil Biol. Biochem., 16, 169-175, https://doi.org/10.1016/0038-0717(84)90108-1, 1984.

Cahill, J. F., Darlington, T. K., Fitzgerald, C., Schoepp, N. G., Beld, J., Burkart, M. D., and Prather, K. A.: Online Analysis of Single Cyanobacteria and Algae Cells under Nitrogen-Limited Conditions Using Aerosol Time-ofFlight Mass Spectrometry, Anal. Chem., 87, 8039-8046, https://doi.org/10.1021/acs.analchem.5b02326, 2015.

Chernoff, C. B. and Orris, G. J.: Data set of world phosphate mines, deposits, and occurrences - Part A, Geologic Data; Part B, Location and Mineral Economic Data: US Geological Survey OpenFile Report 02-156, 2002.

Cortes, C. and Vapnik, V.: Support-vector networks, Mach. Learn., 20, 273-297, https://doi.org/10.1007/BF00994018, 1995.

Creamean, J. M., Suski, K. J., Rosenfeld, D., Cazorla, A., DeMott, P. J., Sullivan, R. C., White, A. B., Ralph, F. M., Minnis, P., Comstock, J. M., Tomlinson, J. M., and Prather, K. A.: Dust and Biological Aerosols from the Sahara and Asia Influence Precipitation in the Western US, Science, 339, 1572-1578, https://doi.org/10.1126/science.1227279, 2013.

Creamean, J. M., Lee, C., Hill, T. C., Ault, A. P., DeMott, P. J., White, A. B., Ralph, F. M., and Prather, K. A.: Chemical properties of insoluble precipitation residue particles, J. Aerosol Sci., 76, 13-27, https://doi.org/10.1016/j.jaerosci.2014.05.005, 2014.

Cziczo, D. J. and Froyd, K. D.: Sampling the composition of cirrus ice residuals, Atmos. Res., 142, 15-31, https://doi.org/10.1016/j.atmosres.2013.06.012, 2014.

Cziczo, D. J., Thomson, D. S., and Murphy, D. M.: Ablation, Flux, and Atmospheric Implications of Meteors Inferred from Stratospheric Aerosol, Science, 291, 1772-1775, https://doi.org/10.1126/science.1057737, 2001.

Cziczo, D. J., Thomson, D. S., Thompson, T. L., DeMott, P. J., and Murphy, D. M.: Particle analysis by laser mass spectrometry (PALMS) studies of ice nuclei and other low number density particles, Int. J. Mass Spectrom., 258, 21-29, https://doi.org/10.1016/j.ijms.2006.05.013, 2006.
Cziczo, D. J., Froyd, K. D., Hoose, C., Jensen, E. J., Diao, M., Zondlo, M. A., Smith, J. B., Twohy, C. H., and Murphy, D. M.: Clarifying the Dominant Sources and Mechanisms of Cirrus Cloud Formation, Science, 340, 1320-1324, 2013.

DeLeon-Rodriguez, N., Lathem, T. L., Rodriguez-R, L. M., Barazesh, J. M., Anderson, B. E., Beyersdorf, A. J., Ziemba, L. D., Bergin, M., Nenes, A., and Konstantinidis, K. T.: Microbiome of the upper troposphere: Species composition and prevalence, effects of tropical storms, and atmospheric implications, P. Natl. Acad. Sci. USA, 110, 2575-2580, https://doi.org/10.1073/pnas.1212089110, 2013.

DeMott, P. J., Cziczo, D. J., Prenni, A. J., Murphy, D. M., Kreidenweis, S. M., Thomson, D. S., Borys, R., and Rogers, D. C.: Measurements of the concentration and composition of nuclei for cirrus formation, P. Natl. Acad. Sci. USA, 100, 14655-14660, https://doi.org/10.1073/pnas.2532677100, 2003.

Després, V. R., Alex Huffman, J., Burrows, S. M., Hoose, C., Safatov, A. S., Buryak, G., Fröhlich-Nowoisky, J., Elbert, W., Andreae, M. O., Pöschl, U., and Jaenicke, R.: Primary biological aerosol particles in the atmosphere: a review, Tellus B, 64, 1-58, https://doi.org/10.3402/tellusb.v64i0.15598, 2012.

Ebert, M., Worringen, A., Benker, N., Mertes, S., Weingartner, E., and Weinbruch, S.: Chemical composition and mixing-state of ice residuals sampled within mixed phase clouds, Atmos. Chem. Phys., 11, 2805-2816, https://doi.org/10.5194/acp-112805-2011, 2011.

Fahlgren, C., Hagstrom, A., Nilsson, D., and Zweifel, U. L.: Annual Variations in the Diversity, Viability, and Origin of Airborne Bacteria, Appl. Environ. Microbiol., 76, 3015-3025, https://doi.org/10.1128/AEM.02092-09, 2010.

Fang, Z., Ouyang, Z., Zheng, H., Wang, X., and Hu, L.: Culturable Airborne Bacteria in Outdoor Environments in Beijing, China, Microb. Ecol., 54, 487-496, https://doi.org/10.1007/s00248-0079216-3, 2007.

Fergenson, D. P., Pitesky, M. E., Tobias, H. J., Steele, P. T., Czerwieniec, G. A., Russell, S. C., Lebrilla, C. B., Horn, J. M., Coffee, K. R., Srivastava, A., Pillai, S. P., Shih, M.-T. P., Hall, H. L., Ramponi, A. J., Chang, J. T., Langlois, R. G., Estacio, P. L., Hadley, R. T., Frank, M., and Gard, E. E.: Reagentless Detection and Classification of Individual Bioaerosol Particles in Seconds, Anal. Chem., 76, 373-378, https://doi.org/10.1021/ac034467e, 2004.

Friedman, B., Zelenyuk, A., Beranek, J., Kulkarni, G., Pekour, M., Gannet Hallar, A., McCubbin, I. B., Thornton, J. A., and Cziczo, D. J.: Aerosol measurements at a high-elevation site: composition, size, and cloud condensation nuclei activity, Atmos. Chem. Phys., 13, 11839-11851, https://doi.org/10.5194/acp-13-118392013, 2013.

Froyd, K. D., Murphy, D. M., Lawson, P., Baumgardner, D., and Herman, R. L.: Aerosols that form subvisible cirrus at the tropical tropopause, Atmos. Chem. Phys., 10, 209-218, https://doi.org/10.5194/acp-10-209-2010, 2010.

Gabey, A. M., Gallagher, M. W., Whitehead, J., Dorsey, J. R., Kaye, P. H., and Stanley, W. R.: Measurements and comparison of primary biological aerosol above and below a tropical forest canopy using a dual channel fluorescence spectrometer, Atmos. Chem. Phys., 10, 4453-4466, https://doi.org/10.5194/acp10-4453-2010, 2010. 
Gallavardin, S., Lohmann, U., and Cziczo, D.: Analysis and differentiation of mineral dust by single particle laser mass spectrometry, Int. J. Mass Spectrom., 274, 56-63, https://doi.org/10.1016/j.ijms.2008.04.031, 2008.

Gard, E., Mayer, J. E., Morrical, B. D., Dienes, T., Fergenson, D. P., and Prather, K. A.: Real-Time Analysis of Individual Atmospheric Aerosol Particles: Design and Performance of a Portable ATOFMS, Anal. Chem., 69, 4083-4091, https://doi.org/10.1021/ac970540n, 1997.

Garimella, S.: A vertically-integrated approach to climate science: from measurements and machine learning to models and policy, PhD dissertation MIT, 2017.

Garimella, S., Huang, Y.-W., Seewald, J. S., and Cziczo, D. J.: Cloud condensation nucleus activity comparison of dryand wet-generated mineral dust aerosol: the significance of soluble material, Atmos. Chem. Phys., 14, 6003-6019, https://doi.org/10.5194/acp-14-6003-2014, 2014.

Griffin, D. W., Garrison, V. H., Herman, J. R., and Shinn, E. A.: African desert dust in the Caribbean atmosphere: Microbiology and public health, Aerobiologia, 17, 203-213, https://doi.org/10.1023/A:1011868218901, 2001.

Griffin, D. W., Westphal, D. L., and Gray, M. A.: Airborne microorganisms in the African desert dust corridor over the mid-Atlantic ridge, Ocean Drilling Program, Leg 209, Aerobiologia, 22, 211226, https://doi.org/10.1007/s10453-006-9033-z, 2006.

Hill, S. C., Pinnick, R. G., Niles, S., Pan, Y.-L., Holler, S., Chang, R. K., Bottiger, J., Chen, B. T., Orr, C.-S., and Feather, G.: Real-time measurement of fluorescence spectra from single airborne biological particles, F. Anal. Chem. Technol., 3, 221-239, https://doi.org/10.1002/(SICI)15206521(1999)3:4/5<221::AID-FACT2>3.0.CO;2-7, 1999.

Hiranuma, N., Möhler, O., Yamashita, K., Tajiri, T., Saito, A., Kiselev, A., Hoffmann, N., Hoose, C., Jantsch, E., Koop, T., and Murakami, M.: Ice nucleation by cellulose and its potential contribution to ice formation in clouds, Nat. Geosci., 8, 273-277, https://doi.org/10.1038/ngeo2374, 2015.

Hoose, C., Kristjánsson, J. E., and Burrows, S. M.: How important is biological ice nucleation in clouds on a global scale?, Environ. Res. Lett., 5, 024009, https://doi.org/10.1088/17489326/5/2/024009, 2010.

Jacobson, M. Z. and Streets, D. G.: Influence of future anthropogenic emissions on climate, natural emissions, and air quality, J. Geophys. Res., 114, D08118, https://doi.org/10.1029/2008JD011476, 2009.

Kaye, P. H., Barton, J. E., Hirst, E., and Clark, J. M.: Simultaneous light scattering and intrinsic fluorescence measurement for the classification of airborne particles, Appl. Opt., 39, 3738, https://doi.org/10.1364/AO.39.003738, 2000.

Kaye, P. H., Stanley, W. R., Hirst, E., Foot, E. V., Baxter, K. L., and Barrington, S. J.: Single particle multichannel bio-aerosol fluorescence sensor, Opt. Express, 13, 3583, https://doi.org/10.1364/OPEX.13.003583, 2005.

Koppelaar, R. H. E. M. and Weikard, H. P.: Assessing phosphate rock depletion and phosphorus recycling options, Global Environ. Chang., 23, 1454-1466, https://doi.org/10.1016/j.gloenvcha.2013.09.002, 2013.

Mahowald, N., Jickells, T. D., Baker, A. R., Artaxo, P., BenitezNelson, C. R., Bergametti, G., Bond, T. C., Chen, Y., Cohen, D. D., Herut, B., Kubilay, N., Losno, R., Luo, C.,
Maenhaut, W., McGee, K. A., Okin, G. S., Siefert, R. L., and Tsukuda, S.: Global distribution of atmospheric phosphorus sources, concentrations and deposition rates, and anthropogenic impacts, Global Biogeochem. Cy., 22, GB4026, https://doi.org/10.1029/2008GB003240, 2008.

Matthias-Maser, S. and Jaenicke, R.: Examination of atmospheric bioaerosol particles with radii $>0.2 \mu \mathrm{m}$, J. Aerosol Sci., 25, 1605 1613, https://doi.org/10.1016/0021-8502(94)90228-3, 1994.

Möhler, O., Georgakopoulos, D. G., Morris, C. E., Benz, S., Ebert, V., Hunsmann, S., Saathoff, H., Schnaiter, M., and Wagner, R. Heterogeneous ice nucleation activity of bacteria: new laboratory experiments at simulated cloud conditions, Biogeosciences, 5, 1425-1435, https://doi.org/10.5194/bg-5-1425-2008, 2008.

Murphy, D. M.: The design of single particle laser mass spectrometers, Mass Spectrom. Rev., 26, 150-165, https://doi.org/10.1002/mas.20113, 2007.

Murphy, D. M., Cziczo, D. J., Hudson, P. K., Thomson, D. S., Wilson, J. C., Kojima, T., and Buseck, P. R.: Particle Generation and Resuspension in Aircraft Inlets when Flying in Clouds, Aerosol Sci. Technol., 38, 401-409, https://doi.org/10.1080/02786820490443094, 2004.

O'Connor, D. J., Healy, D. A., Hellebust, S., Buters, J. T. M., and Sodeau, J. R.: Using the WIBS-4 (Waveband Integrated Bioaerosol Sensor) Technique for the On-Line Detection of Pollen Grains, Aerosol Sci. Technol., 48, 341-349, https://doi.org/10.1080/02786826.2013.872768, 2014.

Orris, G. J. and Grauch, R. I.: Rare earth element mines, deposits, and occurrences: US Geological Survey, Open-File Report 02189, 2002.

Pan, Y., Holler, S., Chang, R. K., Hill, S. C., Pinnick, R. G., Niles, S., and Bottiger, J. R.: Single-shot fluorescence spectra of individual micrometer-sized bioaerosols illuminated by a 351- or a 266-nm ultraviolet laser, Opt. Lett., 24, 116-118, https://doi.org/10.1364/OL.24.000116, 1999.

Platt, J. C.: Probabilistic outputs for support vector machines and comparisons to regularized likelihood methods, in: Advances in Large Margin Classifiers, MIT Press, 61-74, 1999.

Pósfai, M., Li, J., Anderson, J. R., and Buseck, P. R.: Aerosol bacteria over the Southern Ocean during ACE-1, Atmos. Res., 66, 231-240, https://doi.org/10.1016/S0169-8095(03)00039-5, 2003.

Pratt, K. A., Mayer, J. E., Holecek, J. C., Moffet, R. C., Sanchez, R. O., Rebotier, T. P., Furutani, H., Gonin, M., Fuhrer, K., Su, Y., Guazzotti, S., and Prather, K. A.: Development and Characterization of an Aircraft Aerosol Time-of-Flight Mass Spectrometer, Anal. Chem., 81, 1792-1800, https://doi.org/10.1021/ac801942r, 2009a.

Pratt, K. A., DeMott, P. J., French, J. R., Wang, Z., Westphal, D. L., Heymsfield, A. J., Twohy, C. H., Prenni, A. J., and Prather, K. A.: In situ detection of biological particles in cloud ice-crystals, Nat. Geosci., 2, 398-401, 2009 b.

Prospero, J. M., Blades, E., Mathison, G., and Naidu, R.: Interhemispheric transport of viable fungi and bacteria from Africa to the Caribbean with soil dust, Aerobiologia, 21, 1-19, https://doi.org/10.1007/s10453-004-5872-7, 2005.

Sattler, B., Puxbaum, H., and Psenner, R.: Bacterial growth in supercooled cloud droplets, Geophys. Res. Lett., 28, 239-242, https://doi.org/10.1029/2000GL011684, 2001. 
Sesartic, A., Lohmann, U., and Storelvmo, T.: Bacteria in the ECHAM5-HAM global climate model, Atmos. Chem. Phys., 12, 8645-8661, https://doi.org/10.5194/acp-12-8645-2012, 2012.

Silva, P. J., Carlin, R. A., and Prather, K. A.: Single particle analysis of suspended soil dust from Southern California, Atmos. Environ., 34, 1811-1820, https://doi.org/10.1016/S13522310(99)00338-6, 2000.

Smith, D. J. and Griffin, D. W.: Inadequate methods and questionable conclusions in atmospheric life study, P. Natl. Acad. Sci. USA, 110, E2084-E2084, https://doi.org/10.1073/pnas.1302612110, 2013.

Sodeman, D. A., Toner, S. M., and Prather, K. A.: Determination of Single Particle Mass Spectral Signatures from LightDuty Vehicle Emissions, Environ. Sci. Technol., 39, 4569-4580, https://doi.org/10.1021/es0489947, 2005.

Steinke, I., Funk, R., Busse, J., Iturri, A., Kirchen, S., Leue, M., Möhler, O., Schwartz, T., Schnaiter, M., Sierau, B., Toprak, E., Ullrich, R., Ulrich, A., Hoose, C., and Leisner, T.: Ice nucleation activity of agricultural soil dust aerosols from Mongolia, Argentina, and Germany, J. Geophys. Res.-Atmos., 121, 1355913579, https://doi.org/10.1002/2016JD025160, 2016.

Thomson, D. S., Schein, M. E., and Murphy, D. M.: Particle analysis by laser mass spectrometry $\{\mathrm{WB}\}-57$ instrument overview, Aerosol Sci. Technol., 33, 153-169, 2000.

Toprak, E. and Schnaiter, M.: Fluorescent biological aerosol particles measured with the Waveband Integrated Bioaerosol Sensor WIBS-4: laboratory tests combined with a one year field study, Atmos. Chem. Phys., 13, 225-243, https://doi.org/10.5194/acp13-225-2013, 2013.

Twohy, C. H., McMeeking, G. R., DeMott, P. J., McCluskey, C. S., Hill, T. C. J., Burrows, S. M., Kulkarni, G. R., Tanarhte, M., Kafle, D. N., and Toohey, D. W.: Abundance of fluorescent biological aerosol particles at temperatures conducive to the formation of mixed-phase and cirrus clouds, Atmos. Chem. Phys., 16, 8205-8225, https://doi.org/10.5194/acp-16-8205-2016, 2016.

US Geological Survey: 2013 Minerals Yearbook, Rare Earths, 2016 a.

US Geological Survey: Mineral commodity summaries 2016, 128129, available from: https://doi.org/10.3133/70140094, last access: 6 January $2016 \mathrm{~b}$.

Walker, T. W. and Syers, J. K.: The fate of phosphorus during pedogenesis, Geoderma, 15, 1-19, https://doi.org/10.1016/00167061(76)90066-5, 1976.

Wang, R., Balkanski, Y., Boucher, O., Ciais, P., Peñuelas, J., and Tao, S.: Significant contribution of combustion-related emissions to the atmospheric phosphorus budget, Nat. Geosci., 8, 48-54, https://doi.org/10.1038/ngeo2324, 2014.

Wang, Y. P., Law, R. M., and Pak, B.: A global model of carbon, nitrogen and phosphorus cycles for the terrestrial biosphere, Biogeosciences, 7, 2261-2282, https://doi.org/10.5194/bg-7-22612010, 2010.

Wiedinmyer, C., Bowers, R. M., Fierer, N., Horanyi, E., Hannigan, M., Hallar, A. G., McCubbin, I., and Baustian, K.: The contribution of biological particles to observed particulate organic carbon at a remote high altitude site, Atmos. Environ., 43, 4278-4282, https://doi.org/10.1016/j.atmosenv.2009.06.012, 2009.

Xia, Y., Conen, F., and Alewell, C.: Total bacterial number concentration in free tropospheric air above the Alps, Aerobiologia, 29, 153-159, https://doi.org/10.1007/s10453-012-9259-x, 2013.
Yang, X. and Post, W. M.: Phosphorus transformations as a function of pedogenesis: A synthesis of soil phosphorus data using Hedley fractionation method, Biogeosciences, 8, 2907-2916, https://doi.org/10.5194/bg-8-2907-2011, 2011.

Yang, X., Post, W. M., Thornton, P. E., and Jain, A.: The distribution of soil phosphorus for global biogeochemical modeling, Biogeosciences, 10, 2525-2537, https://doi.org/10.5194/bg-102525-2013, 2013.

Zaveri, R. A., Shaw, W. J., Cziczo, D. J., Schmid, B., Ferrare, R. A., Alexander, M. L., Alexandrov, M., Alvarez, R. J., Arnott, W. P., Atkinson, D. B., Baidar, S., Banta, R. M., Barnard, J. C., Beranek, J., Berg, L. K., Brechtel, F., Brewer, W. A., Cahill, J. F., Cairns, B., Cappa, C. D., Chand, D., China, S., Comstock, J. M., Dubey, M. K., Easter, R. C., Erickson, M. H., Fast, J. D., Floerchinger, C., Flowers, B. A., Fortner, E., Gaffney, J. S., Gilles, M. K., Gorkowski, K., Gustafson, W. I., Gyawali, M., Hair, J., Hardesty, R. M., Harworth, J. W., Herndon, S., Hiranuma, N., Hostetler, C., Hubbe, J. M., Jayne, J. T., Jeong, H., Jobson, B. T., Kassianov, E. I., Kleinman, L. I., Kluzek, C., Knighton, B., Kolesar, K. R., Kuang, C., Kubátová, A., Langford, A. O., Laskin, A., Laulainen, N., Marchbanks, R. D., Mazzoleni, C., Mei, F., Moffet, R. C., Nelson, D., Obland, M. D., Oetjen, H., Onasch, T. B., Ortega, I., Ottaviani, M., Pekour, M., Prather, K. A., Radney, J. G., Rogers, R. R., Sandberg, S. P., Sedlacek, A., Senff, C. J., Senum, G., Setyan, A., Shilling, J. E., Shrivastava, M., Song, C., Springston, S. R., Subramanian, R., Suski, K., Tomlinson, J., Volkamer, R., Wallace, H. W., Wang, J., Weickmann, A. M., Worsnop, D. R., Yu, X.-Y., Zelenyuk, A., and Zhang, Q.: Overview of the 2010 Carbonaceous Aerosols and Radiative Effects Study (CARES), Atmos. Chem. Phys., 12, 7647-7687, https://doi.org/10.5194/acp-12-7647-2012, 2012.

Zender, C. S.: Mineral Dust Entrainment and Deposition (DEAD) model: Description and 1990s dust climatology, J. Geophys. Res., 108, 4416, https://doi.org/10.1029/2002JD002775, 2003.

Zhang, X., Smith, K. A., Worsnop, D. R., Jimenez, J., Jayne, J. T., and Kolb, C. E.: A Numerical Characterization of Particle Beam Collimation by an Aerodynamic Lens-Nozzle System: Part I. An Individual Lens or Nozzle, Aerosol Sci. Technol., 36, 617-631, https://doi.org/10.1080/02786820252883856, 2002.

Zhang, X., Smith, K. A., Worsnop, D. R., Jimenez, J. L., Jayne, J. T., Kolb, C. E., Morris, J., and Davidovits, P.: Numerical Characterization of Particle Beam Collimation: Part II Integrated Aerodynamic-Lens-Nozzle System, Aerosol Sci. Technol., 38, 619-638, https://doi.org/10.1080/02786820490479833, 2004.

Ziemba, L. D., Beyersdorf, A. J., Chen, G., Corr, C. A., Crumeyrolle, S. N., Diskin, G., Hudgins, C., Martin, R., Mikoviny, T., Moore, R., Shook, M., Thornhill, K. L., Winstead, E. L., Wisthaler, A., and Anderson, B. E.: Airborne observations of bioaerosol over the Southeast United States using a Wideband Integrated Bioaerosol Sensor, J. Geophys. Res.-Atmos., 121, 85068524, https://doi.org/10.1002/2015JD024669, 2016.

Zawadowicz, M. A.: Improved identification of primary biological aerosol particles using single particle mass spectrometry, https://doi.org/10.7910/DVN/C6V7FL, Harvard Dataverse, 2017. 